\title{
A Summary of Neutronics Information for Irradiation Experiments in the Oak Ridge Research Reactor
}
E. J. Allen
H. T. Kerr

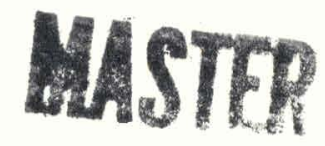

\section{OAK RIDGE NATIONAL LABORATORY}




\section{DISCLAIMER}

This report was prepared as an account of work sponsored by an agency of the United States Government. Neither the United States Government nor any agency Thereof, nor any of their employees, makes any warranty, express or implied, or assumes any legal liability or responsibility for the accuracy, completeness, or usefulness of any information, apparatus, product, or process disclosed, or represents that its use would not infringe privately owned rights. Reference herein to any specific commercial product, process, or service by trade name, trademark, manufacturer, or otherwise does not necessarily constitute or imply its endorsement, recommendation, or favoring by the United States Government or any agency thereof. The views and opinions of authors expressed herein do not necessarily state or reflect those of the United States Government or any agency thereof. 


\section{DISCLAIMER}

Portions of this document may be illegible in electronic image products. Images are produced from the best available original document. 
Printed in the United States of America: Available from National Technical Information Service

U.S. Department of Commerce

5285 Port Royal Road, Springfield, Virginia 22161

Price: Printed Copy $\$ 4.00$; Microfiche $\$ 2.25$

This report was prepared as an account of work sponsored by the United States Government. Neither the United States nor the Energy Research and Development Administration, nor any of their employees, nor any of their contractors, subcontractors, or their employees, makes any warranty, express or implied, or assumes any legal liability or responsibility for the accuracy, completeness or usefulness of any information, apparatus, product or process disclosed, or represents that its use would not infringe privately owned rights. 
ORNL/TM-5271

$\mathrm{UC}-77$ - Gas-Cooled Reactor
Technology

Contract No. W-7405-eng-26

Reactor Division

HTGR BASE TECHNOLOGY PROGRAM

HTGR Fuel Development (189a OH002)

A SUMMARY OF NEUTRONICS INFORMATION FOR IRRADIATION

EXPERIMENTS IN THE OAK RIDGE RESEARCH REACTOR

E. J. Allen H. T. Kerr

MAY 197.6

NOTICE This document contains information of a preliminary nature and was prepared primarily for internal use at the Oak Ridge National Laboratory. It is subject to revision or correction and therefore does not represent a final report.

OAK RIDGE NATIONAL LABORATORY

Oak Ridge, Tennessee 37830

operated by

UNION CARBIDE CORPORATION

for the

ENERGY RESEARCH AND DEVELOPMENT ADMINISTRATION

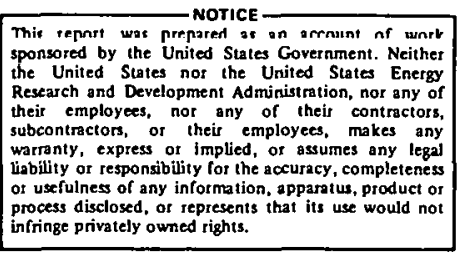

Thir report was prenareet as an arrount nf wnot United States nor the United States Energy their employes, nor any of theif contractors, warranty, express or implied, or assurnes any legal uscfulness of any information, appatatiu, product or process disclosed, of represents that its use would not Gringe privately owned rights. 


\section{THIS PAGE}

\section{WAS INTENTIONALLY \\ LEFT BLANK}




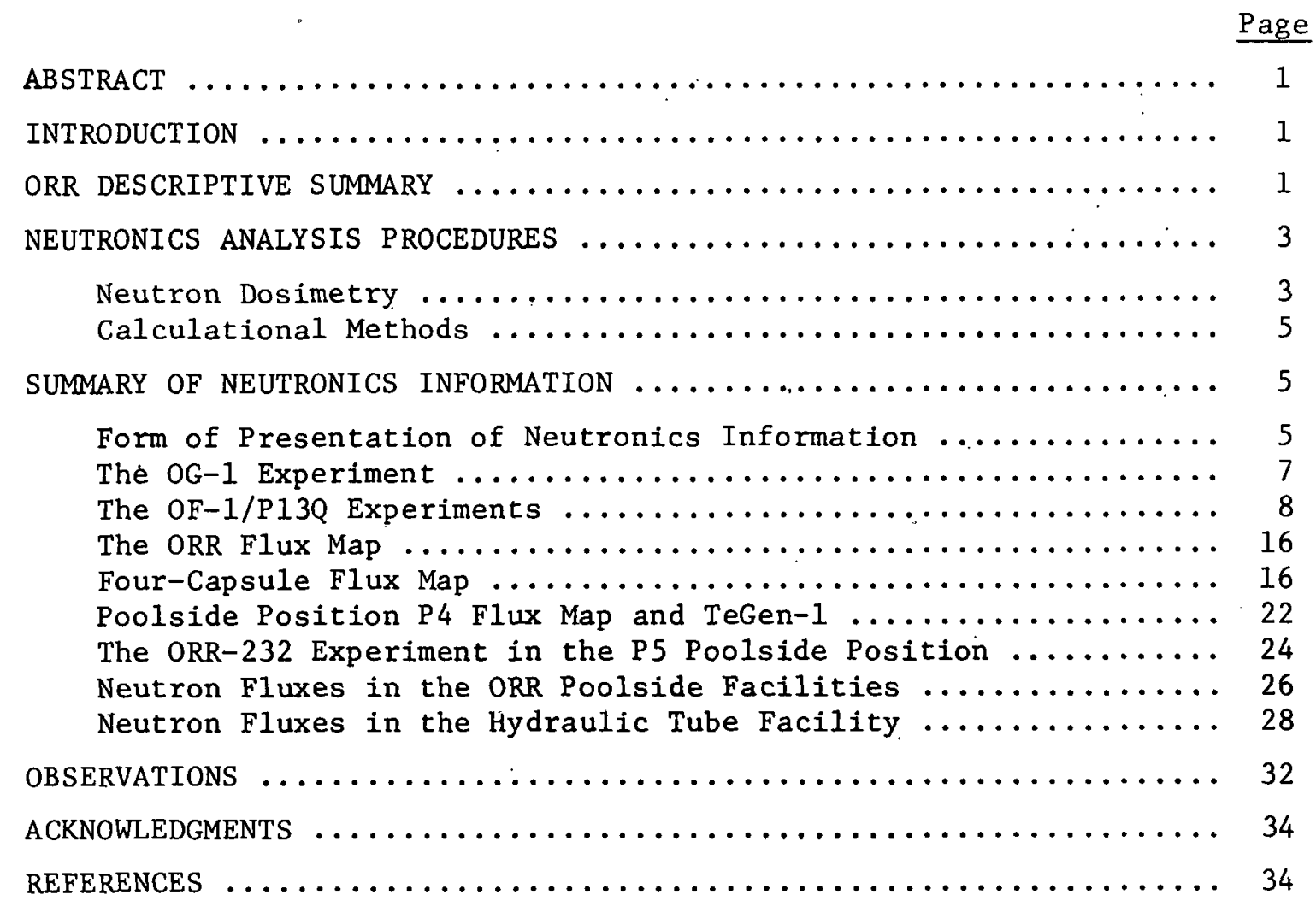




\title{
A SUMMARY OF NEUTRONICS INFORMATION FOR IRRADIATION EXPERIMENTS IN THE OAK RIDGE RESEARCH REACTOR
}

\author{
E. J. Allen H. T. Kerr
}

ABSTRACT

Neutronics information is summarized for several experiments in the irradiation facilities of the Oak Ridge Research Reactor (ORR). Comparisons are made between experimental data and results obtained from calculational models. Factors that significantly influence the neutronic characteristics of the irradiation facilities are identified, and experimental neutron dosimeter materials and techniques are described.

Key words: ORR, neutron flux, neutron spectra, measurement, in-pile tests, reaction rates, calculations

\section{INTRODUCTION}

Considerable neutronics information has been accumulated for experiments irradiated in the facilities of the ORR. Neutron-dosimetry data from these experiments have been analyzed to provide estimates of neutron fluxes and neutron-induced reaction rates in the facilities. In addition, neutronics calculations have been done for a variety of ORR core configurations and experimental conditions. The experimental and calculational techniques have been integrated to provide a base from which neutronic parameters can be predicted and verified for experiments in the ORR core.

This report summarizes the neutronics information obtained for various experiments irradiated in the ORR and describes the experimental and calculational techniques applied in analyses of ORR neutronic parameters.

ORR DESCRIPTIVE SUMMARY

The ORR core consists of a $9 \times 7$ array of plate-type fuel elements, beryllium reflector elements, shim rods, and experimental facilities. 
Each of the elements is approximately 0.076 by 0.076 by $0.813 \mathrm{~m}$, but the fuel elements have an active fuel height of only $0.61 \mathrm{~m}$. A typical core configuration is depicted in Fig. 1. The available experimental facilities include:

1. Aluminum core piece facilities that occupy lattice positions. The number of these facilities is limited by fuel management and control considerations. They are approximately $76 \times 76 \mathrm{~mm}$ with central holes for experimental capsules up to $64 \mathrm{~mm}$ in diameter.

?. 'lhe hydraulis, tuhe facility, which is currently located in the D-8 position.

3. Beryllium reflector elements that have $50.8-\mathrm{mm}$-diam holes for experimental capsules.

4. The poolside facility, which consists of a series of movable tracks on the west side of the core into which capsules may be placed.

5. There are also various beam tubes, but they will not be considered in this report.

The core has six shim control rods, each having an upper poison section consisting of a water-filled cadmium box and a lower fuelfollower section similar to normal fuel elements. The fuel plates in the fuel elements and the shim rods are composed of an aluminum-uranium alloy clad in aluminum. The uranium fuel is $93 \%$ enriched in ${ }^{235} \mathrm{U}$. Water is the coolant moderator, and the average water temperature is about $51^{\circ} \mathrm{C}$.

The ORR produces $30 \mathrm{MW}(t)$ at full power and operates on an eightweek cycle with refueling shutdowns every 10 to 14 days. Shim rods are changed or repositioned at the end of each cycle. Al preseul, llie four shim rods in positions $\mathrm{B} 4, \mathrm{~B} 6, \mathrm{D} 4$, and $\mathrm{D} 6$ operate as a group, and the two rods in F4 and F6 stay fully withdrawn during power operations.

A more comprehensive description of the ORR is given in Ref. 1 . 
ORNL-DWG 76-5724

$$
\begin{gathered}
\text { Be - Beryllium element } \\
\text { Fuel - Fuel element } \\
\text { SR - Shim rod } \\
\text { Exp - Experiment or } \\
\text { experimental facility } \\
\text { PoOL }
\end{gathered}
$$

\begin{tabular}{|c|c|c|c|c|c|c|c|c|}
\hline $\begin{array}{l}\mathrm{A}-1 \\
\mathrm{Be}\end{array}$ & $\begin{array}{l}\mathrm{A}-2 \\
\mathrm{Be}\end{array}$ & $\begin{array}{l}\text { A-3 } \\
\text { Fue1 }\end{array}$ & $\begin{array}{l}\text { A-4 } \\
\text { Fue1 }\end{array}$ & $\begin{array}{l}\text { A-5 } \\
\text { Fuel }\end{array}$ & $\begin{array}{l}\text { A-6 } \\
\text { Fuel }\end{array}$ & $\begin{array}{l}\mathrm{A}-7 \\
\mathrm{Be}\end{array}$ & $\begin{array}{l}\mathrm{A}-8 \\
\mathrm{Be}\end{array}$ & $\begin{array}{l}\mathrm{A}-9 \\
\mathrm{Be}\end{array}$ \\
\hline $\begin{array}{l}\mathrm{B}-1 \\
\mathrm{Be}\end{array}$ & $\begin{array}{l}\mathrm{B}-2 \\
\mathrm{Be}\end{array}$ & $\begin{array}{l}\text { B-3 } \\
\text { Fuel }\end{array}$ & $\begin{array}{l}B-4 \\
\text { SR }\end{array}$ & $\begin{array}{l}\text { B-5 } \\
\text { Fue1 }\end{array}$ & $\begin{array}{l}\text { B-6 } \\
\text { SR }\end{array}$ & $\begin{array}{l}\text { B-7 } \\
\text { Fuel }\end{array}$ & $\begin{array}{l}\mathrm{B}-8 \\
\mathrm{Be}\end{array}$ & $\begin{array}{l}\mathrm{B}-9 \\
\mathrm{Be}\end{array}$ \\
\hline $\begin{array}{l}\mathrm{C}-1 \\
\mathrm{Be}\end{array}$ & $\begin{array}{l}\mathrm{C}-2 \\
\text { Fuel }\end{array}$ & $\begin{array}{l}\text { C-3 } \\
\text { Fuel }\end{array}$ & $\begin{array}{l}\text { C-4 } \\
\text { Fuel }\end{array}$ & $\begin{array}{l}\text { C-5 } \\
\text { Fue1 }\end{array}$ & $\begin{array}{l}\text { C-6 } \\
\text { Fuel }\end{array}$ & $\begin{array}{l}\text { C-7 } \\
\text { Fuel }\end{array}$ & $\begin{array}{l}\text { C-8 } \\
\text { Exp }\end{array}$ & $\begin{array}{l}\mathrm{C}-9 \\
\mathrm{Be}\end{array}$ \\
\hline $\begin{array}{l}\mathrm{D}-1 \\
\mathrm{Be}\end{array}$ & $\begin{array}{l}\text { D-2 } \\
\text { Fue1 }\end{array}$ & $\begin{array}{l}\text { D-3 } \\
\text { Fue1 }\end{array}$ & $\begin{array}{l}D-4 \\
S R\end{array}$ & $\begin{array}{l}D-5 \\
\text { Fue1 }\end{array}$ & $\begin{array}{l}\mathrm{D}-6 \\
\text { SR }\end{array}$ & $\begin{array}{l}\mathrm{D}-7 \\
\text { Fuel }\end{array}$ & $\begin{array}{l}\text { D-8 } \\
\text { Exp }\end{array}$ & $\begin{array}{l}\text { D-9 } \\
\text { Be }\end{array}$ \\
\hline $\begin{array}{l}E-1 \\
B e\end{array}$ & $\begin{array}{l}\text { E-2 } \\
\text { Fuel }\end{array}$ & $\begin{array}{l}\text { E-3 } \\
\text { Exp }\end{array}$ & $\begin{array}{l}\text { E-4 } \\
\text { Fue1 }\end{array}$ & $\begin{array}{l}\text { E-5 } \\
\text { Fuel }\end{array}$ & $\begin{array}{l}\text { E-6 } \\
\text { Fue1 }\end{array}$ & $\begin{array}{l}\text { E-7 } \\
\text { Fuel }\end{array}$ & $\begin{array}{l}\text { E-8 } \\
\text { Exp }\end{array}$ & $\begin{array}{l}\mathrm{E}-9 \\
\mathrm{Be}\end{array}$ \\
\hline $\begin{array}{l}\mathrm{F}-1 \\
\mathrm{Be}\end{array}$ & $\begin{array}{l}\text { F-2 } \\
\text { Fuel }\end{array}$ & $\begin{array}{l}\text { F-3 } \\
\text { Fuel }\end{array}$ & $\begin{array}{l}F-4 \\
S R\end{array}$ & $\begin{array}{l}\text { F-5 } \\
\text { Fue1. }\end{array}$ & $\begin{array}{l}F-6 \\
S R\end{array}$ & $\begin{array}{l}F-7 \\
\operatorname{Exp}\end{array}$ & $\begin{array}{l}\mathrm{F}-8 \\
\mathrm{Be}\end{array}$ & $\begin{array}{l}\mathrm{F}-9 \\
\mathrm{Be}\end{array}$ \\
\hline $\begin{array}{l}\mathrm{G}-1 \\
\mathrm{Be}\end{array}$ & $\begin{array}{l}\mathrm{G}-2 \\
\mathrm{Be}\end{array}$ & $\begin{array}{l}\mathrm{G}-3 \\
\mathrm{Be}\end{array}$ & $\begin{array}{l}\mathrm{G}-4 \\
\mathrm{Be}\end{array}$ & $\begin{array}{l}\mathrm{G}-5 \\
\mathrm{Be}\end{array}$ & $\begin{array}{l}\text { G-6 } \\
\mathrm{Be}\end{array}$ & $\begin{array}{l}\mathrm{G}-7 \\
\mathrm{Be}\end{array}$ & $\begin{array}{l}\mathrm{G}-8 \\
\mathrm{Be}\end{array}$ & $\begin{array}{l}\text { G-9 } \\
\mathrm{Be}\end{array}$ \\
\hline
\end{tabular}

Fig. 1. Typical ORR core configuration.

\section{NEUTRONICS ANALYSIS PROCEDURES}

\section{Neutron Dosimetry}

Neutron-dosimetry techniques are generally used to experimentally determine neutronic parameters in an 1rradiation facillty. Specific dosimeter materlals are inserted into the facility, irradiated for a known period, removed, and the induced activities measured. These activities are analyzed in terms of defined nuclear properties (i.e., cross, sections) to provide estimates of neutron fluxes and/or reaction rates of interest. 
Dosimeter materials are selected primarily on the basis of their neutronic properties, although their chemical compatibility with surrounding materials and physical properties such as melting point must be considered. Some of the basic dosimeter elements are cobalt, iron, titanium, silver, nickel, gold, thorium, and uranium. The fabricated dosimeter material may be a pure metal, an alloy, or an oxide and may be irradiated either bare or encapsulated.

Typical reactions that lead to measurable unstable isotopes are:

$$
\begin{array}{ll}
{ }^{59} \mathrm{Co}(\mathrm{n}, \gamma){ }^{60} \mathrm{Co} & { }^{109} \mathrm{Ag}(\mathrm{n}, \gamma) 110 \mathrm{~m}_{\mathrm{Ag}} \\
{ }^{54} \mathrm{Fe}(\mathrm{n}, \mathrm{p}){ }^{54} \mathrm{Mn} & { }^{14 \%} \mathrm{Au}(\mathrm{n}, \gamma){ }^{198} \mathrm{Au} \\
{ }^{58} \mathrm{Fe}(\mathrm{n}, \gamma){ }^{59} \mathrm{Fe} & { }^{232} \mathrm{Th}(\mathrm{n}, \gamma)^{233} \mathrm{~Pa} \\
{ }^{46} \mathrm{Ti}(\mathrm{n}, \mathrm{p}){ }^{46} \mathrm{Sc} & { }^{235} \mathrm{U}(\mathrm{n}, \mathrm{f}) \text { fission products } \\
{ }^{47} \mathrm{Ti}(\mathrm{n}, \mathrm{p})^{47} \mathrm{Sc} & { }^{58} \mathrm{Ni}(\mathrm{n}, \mathrm{p})^{58} \mathrm{Co}
\end{array}
$$

In each case, irradiation of the target isotope (e.g., ${ }^{59} \mathrm{Co}$ ) produces an unstable product isotope $\left(\mathrm{e} . \mathrm{g} .,{ }^{60} \mathrm{Co}\right)$ whose decay activity is measured by a gamma spectrometer. The measured activity is then used with the irradiation history to infer the production rate of the product isotope.

If neutron fluxes or reaction rates other than those measured are desired, the neutron energy speclrum mist be determined. The neutron energy spectrum can be approximated by numerical techniques or can be assumed to have an appropriate analytic form.

In one method, neutron energy spectra are calculated by a computer code model of the irradiation facility. The most represtulative energy spectrum for the facility is Llien selected from thcoc calculated spectra by minimizing differences between the calculated and the measured reaction rates. In a oecond method, which is referred to as spectrum unfolding, an assumed spectrum (which may be a spectrum obtained by the first method) is modified to fit the reaction rate data. Several computer codes have been developed that employ variations of this method.2,3

The first method was used exclusively in the analysis of reaction rate data reported here; neutron energy spectra were calculated with the XSDRNPM code. 4 


\section{Calculational Methods}

In addition to the direct dosimetry in irradiation tests, several calculational analyses have been made to assist in the determination of neutronic parameters in the ORR irradiation facilities. Multigroup, onedimensional, discrete-ordinates calculations with. XSDRNPM are routinely run to provide neutron energy spectra for experiments in various regions of the ORR. Also, a seven-group, three-dimensional diffusion theory neutronics model of the ORR has been developed with the computer code VENTURE. ${ }^{5}$ This model calculates neutron fluxes and reaction rates at any position in the ORR core. More information on this model is provided in Ref. 6 . However, the diffusion theory model is not adequate for the poolside facilities of the ORR because the anisotropic scattering in the water cannot be properly treated with diffusion theory. A twodimensional discrete-ordinates transport code or a Monte Carlo code would be required to treat both the anisotropic neutron scattering and the geometric heterogeneities of the poolside facilities.

SUMMARY OF NEUTRONICS INFORMATION

Form of Presentation of Neutronics Information

Neutron fluxes or neutron-induced reaction rates are given at various positions within the experiments or experimental facilities. The neutron fluxes are generally given as total fluxes or fluxes above $0.18 \mathrm{MeV}$ :

Total neutron flux $=\int_{0}^{\infty} \phi(E) \mathrm{dE} \doteq \phi_{\mathrm{T}}$,

Flux above $0.18 \mathrm{MeV}=\int_{0.18 \mathrm{MeV}}^{\infty} \phi(E) \mathrm{dE}$.

The flux above $0.18 \mathrm{Mev}$, called the graphite damage flux, has been used as a comparative index of the atomic displacement rate in graphite. More information on graphlte damage fluxes can be found in Ref. 7 . 
Estimates of neutron-induced reaction rates [Eq. (3)] can be obtained from the total neutron fluxes and appropriate spectrum-weighted cross sections [Eq. (4)] :

$$
\mathrm{RR}^{i j}=\sigma_{\mathrm{T}}^{i j} \phi_{\mathrm{T}}
$$

reaction rate for $i$ th nuclide and $j$ th reaction type, and

$$
\sigma_{T^{\prime}}^{i j}=\frac{\int_{0}^{\infty} \sigma^{i j}(E) \phi(E) d E}{\int_{0}^{\infty} \phi(E) d E} .
$$

However, in each experiment, there is a unfque neutron-flux energy spectrum. Because of this, the total cross section $\sigma_{T}^{i j}$ can be different for each experiment and for each position in the experiment. Presenting unique cross sections for all the nuclides and reaction types of interest for each experiment reported here would require excessive documentation. However, the following method can be used to obtain approximate reaction rates from the reported total fluxes with available standard cross-section information. Consider the equation

$$
R R=\phi_{T}\left(f \sigma_{0}+k R I\right) \text {, }
$$

where

$$
\begin{aligned}
& \phi_{\mathrm{T}}=\text { total flux, } \\
& \sigma_{0}=2200-\mathrm{m} / \mathrm{sec} \text { cross sèction, } \\
& \mathrm{RI}=\text { resonançe integral }=\int_{0.5 \mathrm{MeV}}^{\infty} \frac{\mathrm{i}}{\mathrm{E}} \sigma(\mathrm{E}) \mathrm{dE} \text {, } \\
& \mathrm{n} \text { - reaction rata, } \\
& f, k=\text { constants for a particular neutron-flux energy spectrum. } \\
& \text { Equation (5) can be used to calculate rates of reactions that are }
\end{aligned}
$$


and ${ }^{109} \mathrm{Ag}(\mathrm{n}, \gamma){ }^{110 \mathrm{~m}_{\mathrm{Ag}}}$ for each energy spectrum. The $2200-\mathrm{m} / \mathrm{sec}$ cross sections and resonance integrals for each of these reactions are 37.3 and $70 \mathrm{~b}$ for ${ }^{59} \mathrm{Co}$ and 4.1 and $70 \mathrm{~b}$ for ${ }^{109} \mathrm{Ag}$.

The advantage of this method is that for each experiment, if the total fluxes are given, only values for $f$ and $k$ are necessary in order to estimate reaction rates for most reactions of interest. Throughout this report, values for $f$ and $k$ will be given for many of the experiments. Readers interested in specific reaction rates within an experiment can then estimate them.

\section{The OG-1 Experiment}

The OG-1 experiment was designed and built by General Atomic Company (GAC) to test graphites for use in High-Temperature Gas-Cooled Reactor (HTGR) systems. A total graphite damage fluence (time-integrated neutron flux above $0.18 \mathrm{MeV}$ ) of $3.5 \times 10^{21}$ neutrons $/ \mathrm{cm}^{2}$ was planned for this experiment. The OG-1 instrumented capsule was placed in the $\mathrm{C}-3$ lattice position of the ORR and irradiated in fuel cycles 113-A (June 23, 1973) through cycle 115-E (Dec. 2, 1973) to accumulate a total exposure of 3994 MWd, which corresponds to an average damage fluence of $3.5 \times 10^{14}$ neutrons/ $\mathrm{cm}^{2}$.

An extensive neutron-dosimetry program was developed for the OG-1 experiment. Dosimeter materials were placed within the containment of the experimental capsule to provide data for ful1-exposure conditions. These dosimeters were designed by GAC; the analysis of the induced activities in these dosimeters is reported in Ref. 8.

Dosimeters were also irradiated in the aluminum core piece of the C-3 facility to estimate the traversal and axial flux gradients across the experiment and to determine the influence of changes in the core configuration on flux magnitudes. Single- and multicycle irradiations of dosimeter materials were made in the $\mathrm{C}-3$ facility. These irradiations are summarized in Table 1.

Fluxes derived from the data for each of these dosimeter irradiations are presented in Fig. 2. The fluxes decrease about $10 \%$ from the southwest corner to the southeast corner of the C-3 facility and, at a given position, 
Table 1. Dosimeter irradiations in $\mathrm{C}-3$ facility

\begin{tabular}{clc}
\hline Dosimeter set & Location & Cycles \\
\hline G-1 & SW corine & $11.4-A$ \\
$G-2$ & SE & $114-A$ \\
G-4 & SW & $114-A$ to 115-E \\
G-3 & SE & $114-A$ to 115-E \\
\hline
\end{tabular}

vary about $6 \%$ between different cycles. The constants $f$ and $k$ for the neutron-flux spectrum at ail positions in the aluminum core plece of the C-3 facility are 0.1969 and 0.0204 respectively.

\section{The $0 F-1 / P 13 Q$ Experiments}

The $\mathrm{OF}-1 / \mathrm{P} 13 \mathrm{Q}$ irradiation experiments were designed to test candidate fuels for use in HTGR systems with fuel temperatures in the 900 to $1200^{\circ} \mathrm{C}$ range and with graphite damage fluences up to $8 \times 10^{21}$ neutrons $/ \mathrm{cm}^{2}$. The experimental capsule was placed in an aluminum core piece in the E-3 position of the ORR and irradiated from the start of ORR fuel cycle 114 (Aug. 29, 1975) through cycle 123 (Feb. 23, 1975). The capsule containing the experiments had two chambers. The upper chamber $(0.41 \mathrm{~m})$ contained a GAC fuel specimen and was designated $P 13 Q$, and the lower chamber $(0.20 \mathrm{~m})$ contained an ORNL fuel specimen and was designated OF-1.

Neutron dosimeters were loaded inside both the OF-I and P13Q capsules to determine reaction rates in the fuel pins and neutron-flux magnitudes and gradients. UlWN dosimeter packages were placed within the graphitic body of the OF-1 experiment as shown in Fig. 3, and GAC dosimeter packages were placed in $\mathrm{P} 13 \mathrm{Q}$ as described in Ref. 8. Also, single- and multicycle dosimeter irradiations were made over the full length of the aluminum core piece in the E-3 facility to determine magnitudes and gradients of neutron fluxes for different ORR core configurations. The dosimeter irradiations in the aluminum core piece are summarized in Table 2. 


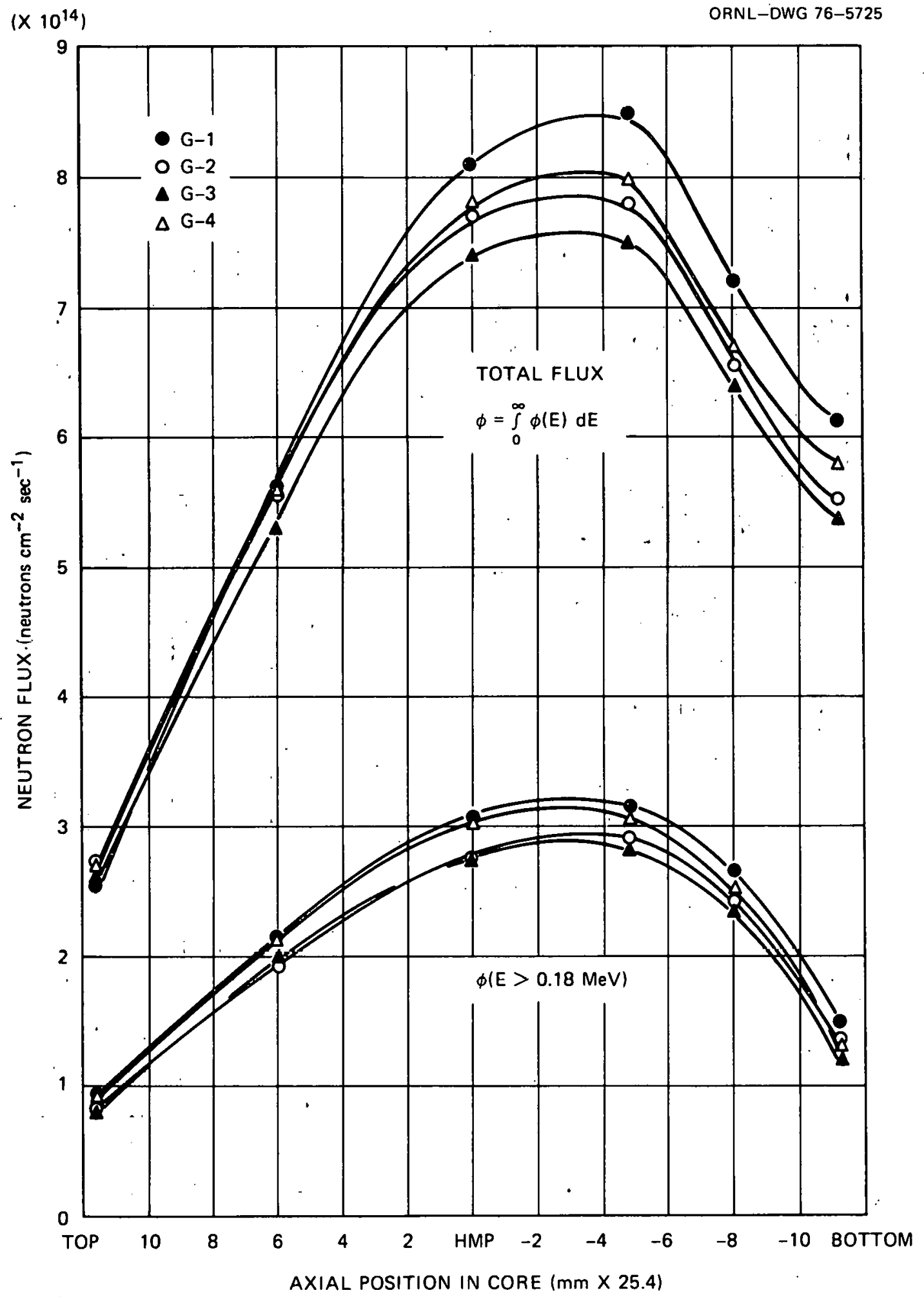

Fig. 2. Neutron fluxes in the OG-1 experimental facility. 

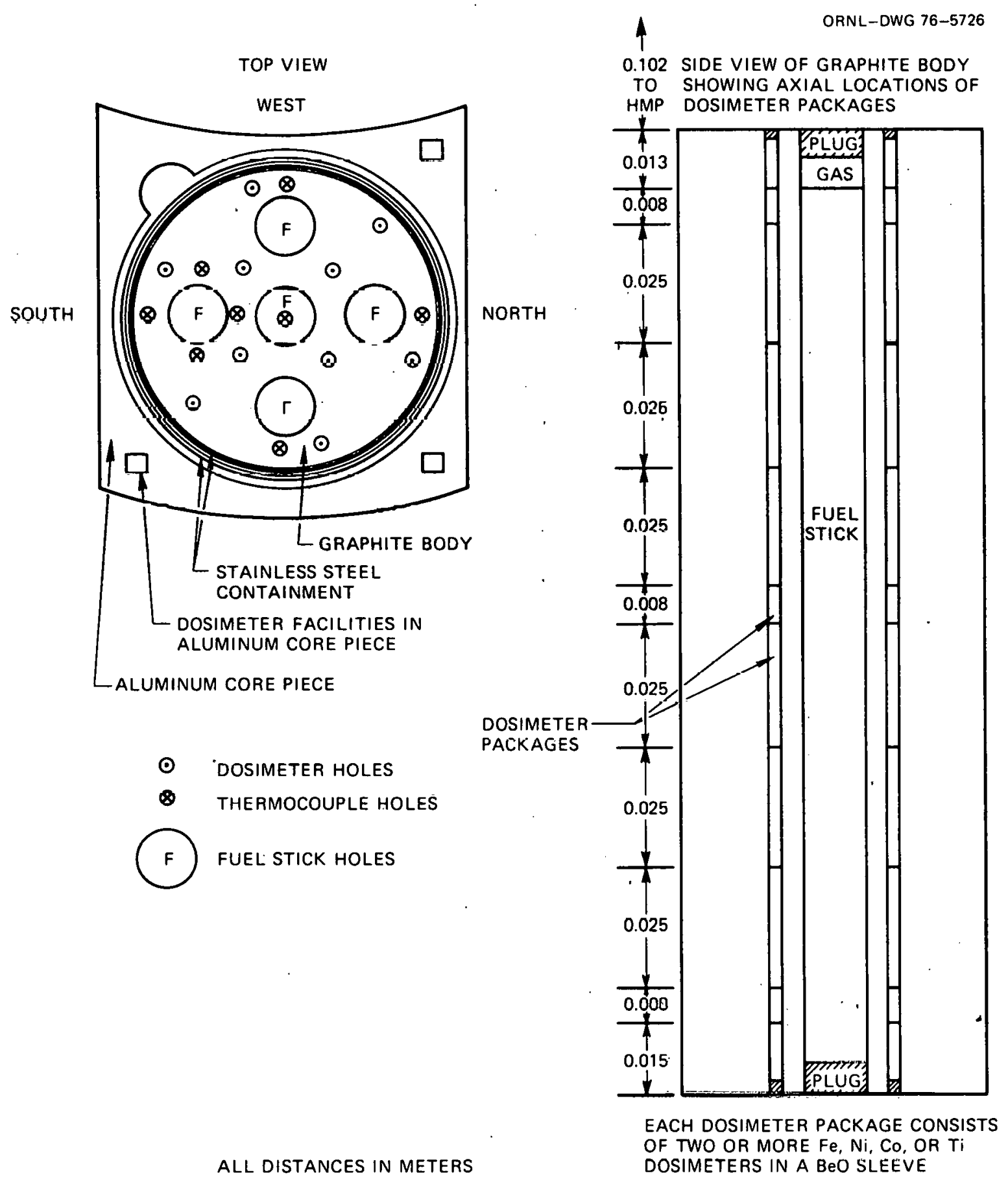

ALL DISTANCES IN METERS

OF TWO OR MORE $\mathrm{Fe}, \mathrm{Ni}$, $\mathrm{Co}$ OR Ti DOSIMETERS IN A BEO SLEEVE

Fig. 3. The OF-1 experimental capsule. 
Table 2. Dosimeter irradiations

in aluminum core piece

\begin{tabular}{|c|c|c|}
\hline $\begin{array}{l}\text { Dosimeter } \\
\text { set }\end{array}$ & $\begin{array}{l}\text { Position in } \\
\text { E-3 facility }\end{array}$ & ORR cycles \\
\hline$s-1$ & NW corner & $114-A$ \\
\hline$s-2$ & $\mathrm{NE}$ & $114-\mathrm{A}$ \\
\hline$L-1$ & $\mathrm{SE}$ & 114-A. \\
\hline$s-5$ & NW & $117-\mathrm{A}$ \\
\hline$s-6$ & $\mathrm{NE}$ & $117-\mathrm{A}$ \\
\hline $\mathrm{L}-3$ & SE & $117-\mathrm{A}$ \\
\hline$s-3$ & NW & $114-\mathrm{B}$ to $116-\mathrm{D}$ \\
\hline$S-4$ & $\mathrm{NE}$ & $114-\mathrm{B}$ to $116-\mathrm{D}$ \\
\hline $\mathrm{L}-2$ & SE & $114-B$ to $116-D$ \\
\hline
\end{tabular}

The induced activities in the various materials, which included iron, cobalt, silver, and titanium, were measured, and each dosimetry capsule was analyzed, as described below.

An XSDRNPM calculation was performed for a one-dimensional model of the OF-1 capsule to obtain typical neutron energy spectra for the fuel sticks, graphite body, and aluminum core piece. With these spectra, the total fluxes and damage fluxes required to induce the measured activities in the dosimeters were calculated; these are plotted in Figs. 4 to 6 . These estimated fluxes in the aluminum core piece indicated that the peak and average damage fluences in the OF- 1 fuel specimen were about $11.0 \times 10^{21}$ and about $8.3 \times 10^{21}$ neutrons $/ \mathrm{cm}^{2}$, respectively, which satisfies the design criteria for the OF-1 experiment. The flux gradients from the northwest corner to the southeast corner of the E-3 facility were 10 to $20 \%$, and the magnitudes of neutron flux in the facility changed less than $5 \%$ for different core configurations studied. The constants $f$ and $k$ for the neutronflux spectrum in the aluminum core piece are 0.1969 and 0.024 respectively.

After removal of the OF-1 capsule from the ORR, the dosimeters in the graphite holder were recovered and their induced activities measured. Anomalies were observed in the ${ }^{54} \mathrm{Mn}$ activity produced by the ${ }^{54} \mathrm{Fe}(\mathrm{n}, \mathrm{p}){ }^{54} \mathrm{Mn}$ reaction; the measured ${ }^{54} \mathrm{Mn}$ activity peaked at the lower end of the capsule. This ${ }^{54} \mathrm{Mn}$ distribution is not realistic and probably resulted from the 


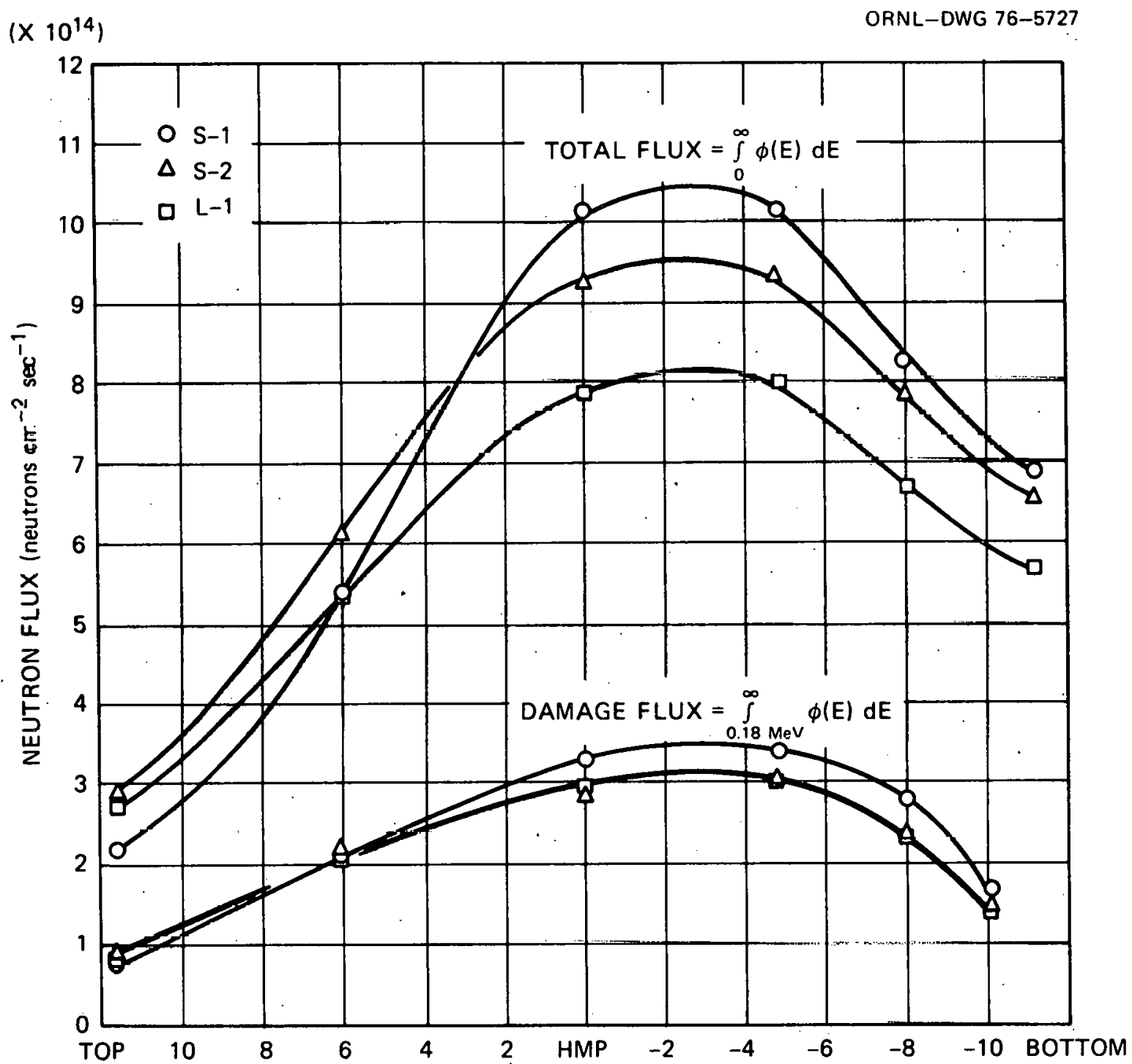

AXIAL POSITION IN CORE $(\mathrm{mm} \times 25.4)$

Fig. 4. Neutron fluxes in the OF-1 experimental facility - cycle 114-A.

diffusion of manganese from hot regions of the iron monitors. However, relative magnitudes of the other induced activities were in agreement, and the following analysis was made.

Using the neutron energy spectra obtained from the XSDRNPM model of the E-3 facility and an appropriate irradiation history, the total fluxes required to induce the measured activities were calculated for the 


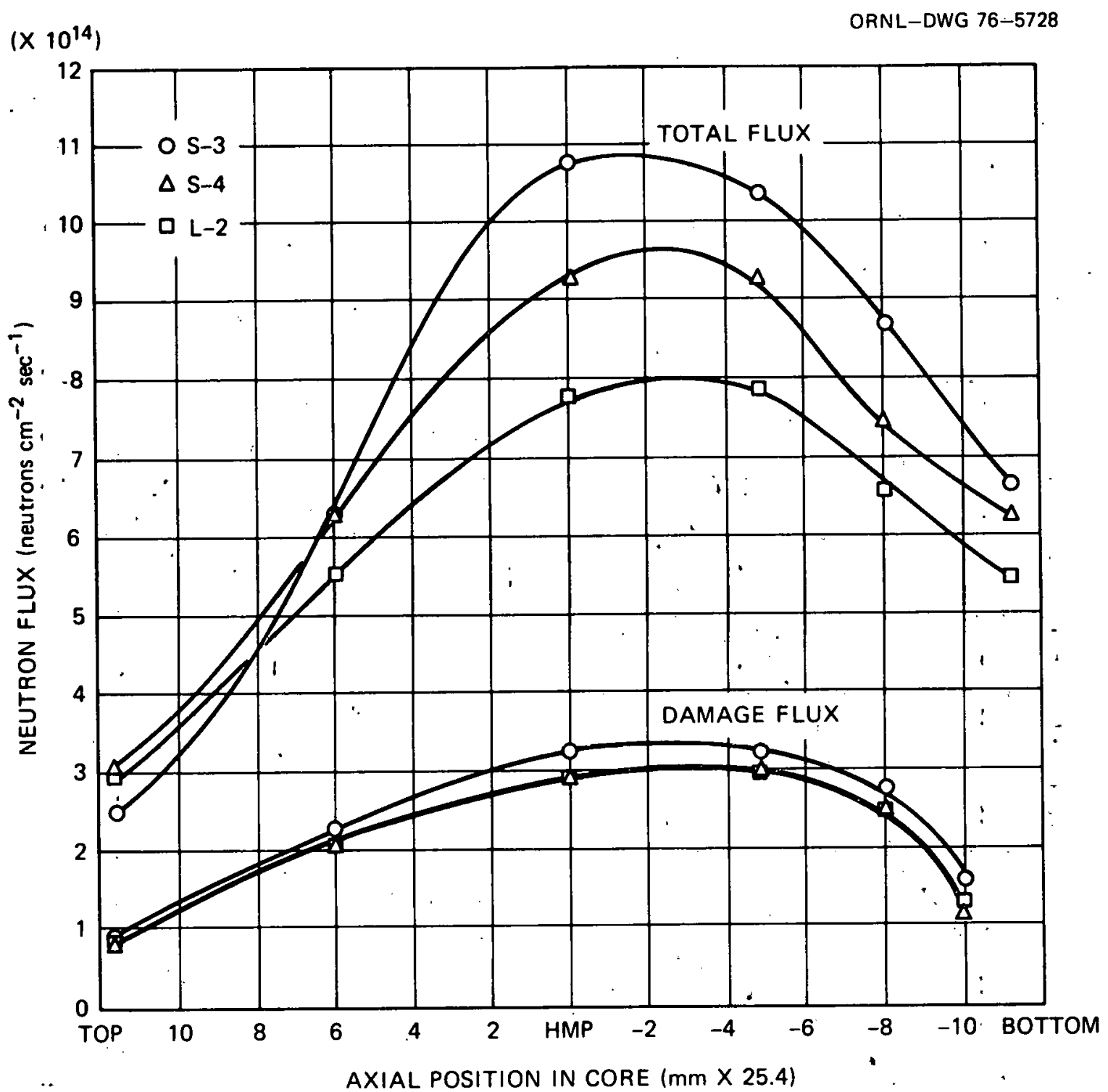

Fig. 5. Neutron fluxes in the OF-1 experimental facility - cycle 117-A .

dosimeters obtained from the graphite holder. Average fluxes for each of the fuel pins were then estimated and are given in Fig. 7. The constants $f$ and $k$ for the neutron flux spectrum in the fuel sticks are 0.1657 and 0.0201 respectively. 


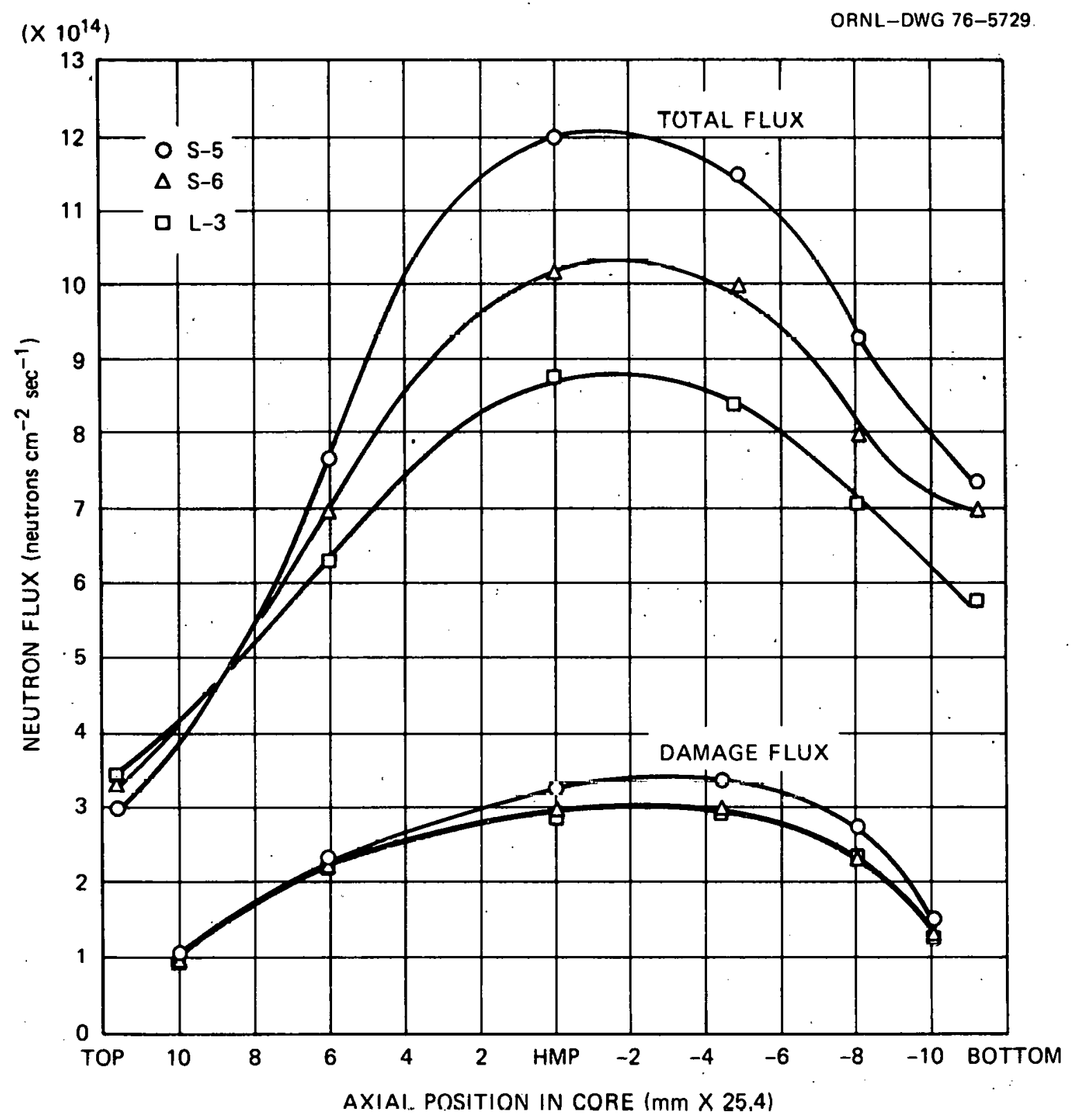

Fig. 6. Neutron fluxes in the $O F-1$ experimental facility - cycles $114-B$ to $116-D$. 


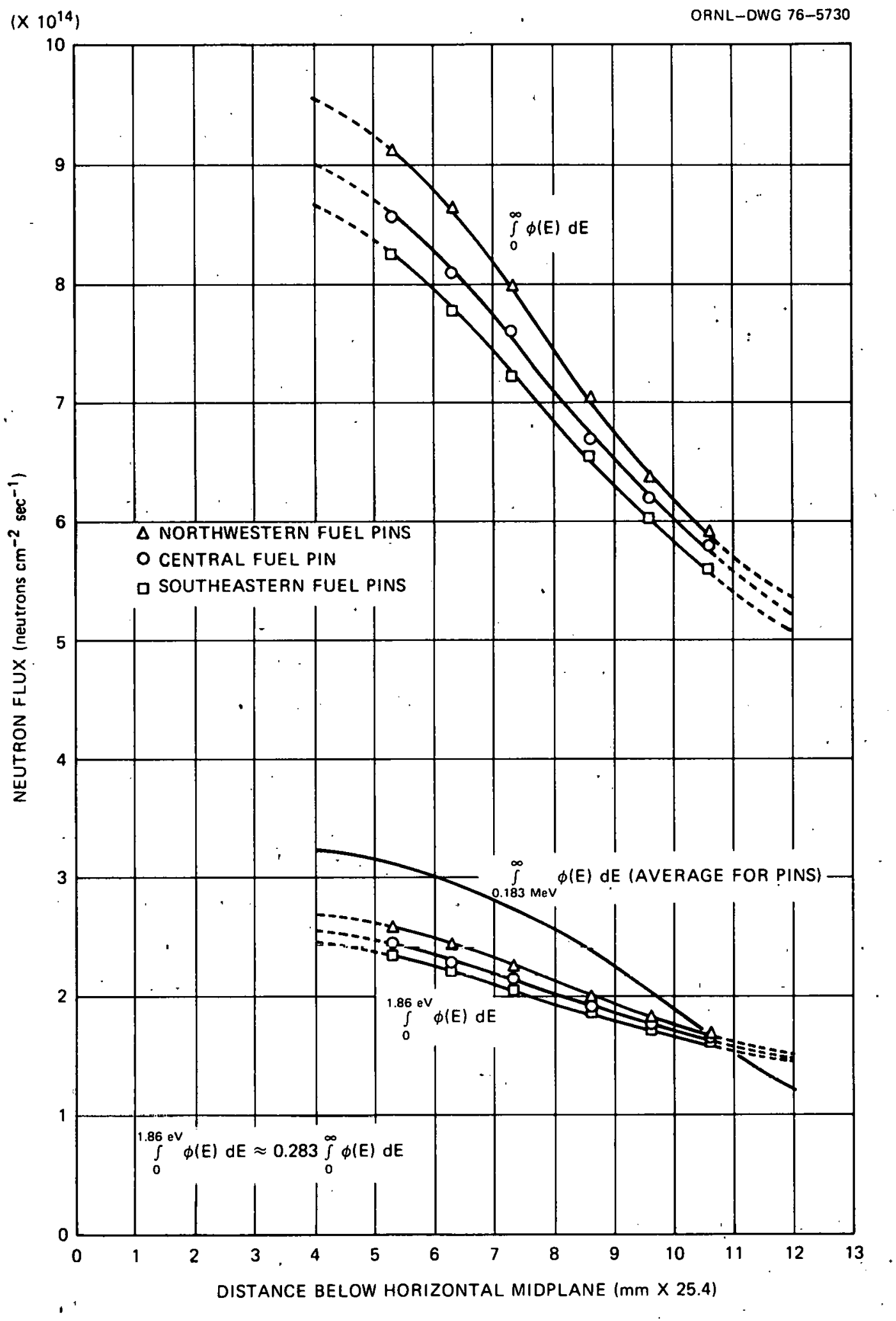

F1g. 7. Full-power neutron fluxes for OFw1 fuel pins. 
The ORR Flux Map

The purpose of the mapping was to test a general computational model of the neutron fluxes in the ORR using the neutron diffusion code VENTURE. An accurate, flexible, and easily operated model would be very useful for routine experimental analyses as well as for future neutronics work.

Prior to ORR cycle 118-A, an extensive flux, map of the ORR core was made. Aluminum-cobalt wires and iron wires were loaded into 3.2-mm-OD aluminum tubes, and the tubes were then placed in central positions of all the tuèl elements, shim rods, and most of the beryllium elements. The ORR was then operated at $1 \%$ power for $10 \mathrm{hr}$ in the core configuration shown in Fig. 8. After the irradiation, the wires were removed, cut into $25.4-\mathrm{mm}$ lengths, and analyzed to determine the induced ${ }^{59} \mathrm{Fe},{ }^{54} \mathrm{Mn}$, and ${ }^{60} \mathrm{Co}$ activities.

The dosimeter activity profiles calculated with the VENTURE model are compared with the experimental activities for two lattice positions in Figs. 9 and 10. The axial profiles are very similar, and the absolute agreement is generally within $10 \%$. The calculated multiplication factor for this core configuration was 1.012 .

The good agreement between calculation and experiment confirms the validity of the calculational model. The principal 1imitation of this model is due to the use of diffusion theory, which does not consider anisotropic scattering of neutrons. Because of this, the calculated fluxes get progressively less accurate away from fuel regions.

Further information on the calculational model may be found in Ref. 6 .

\section{Four-Capsule Flux Map}

In early 1975, two additional irradiation facilities were needed in the ORR core for HTGR fuel and graphite tests. The E-5 and E-7 lattice positions were selected, and the neutronic characteristics of those facilities were evaluated. Also, information was needed concerning the influence of a given experiment on experiments in nearby facilities.

Mockup capsules similar to the proposed experimental capsules were designed, fabricated, and irradiated in the aluminum core pieces for E-5 


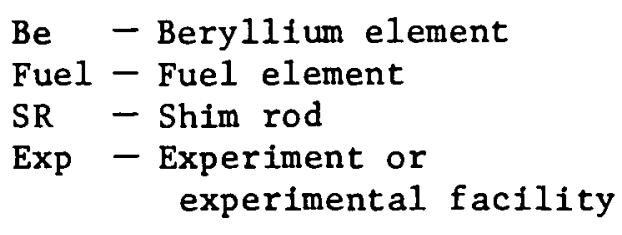

ORNL-DWG 76-5731

POOL

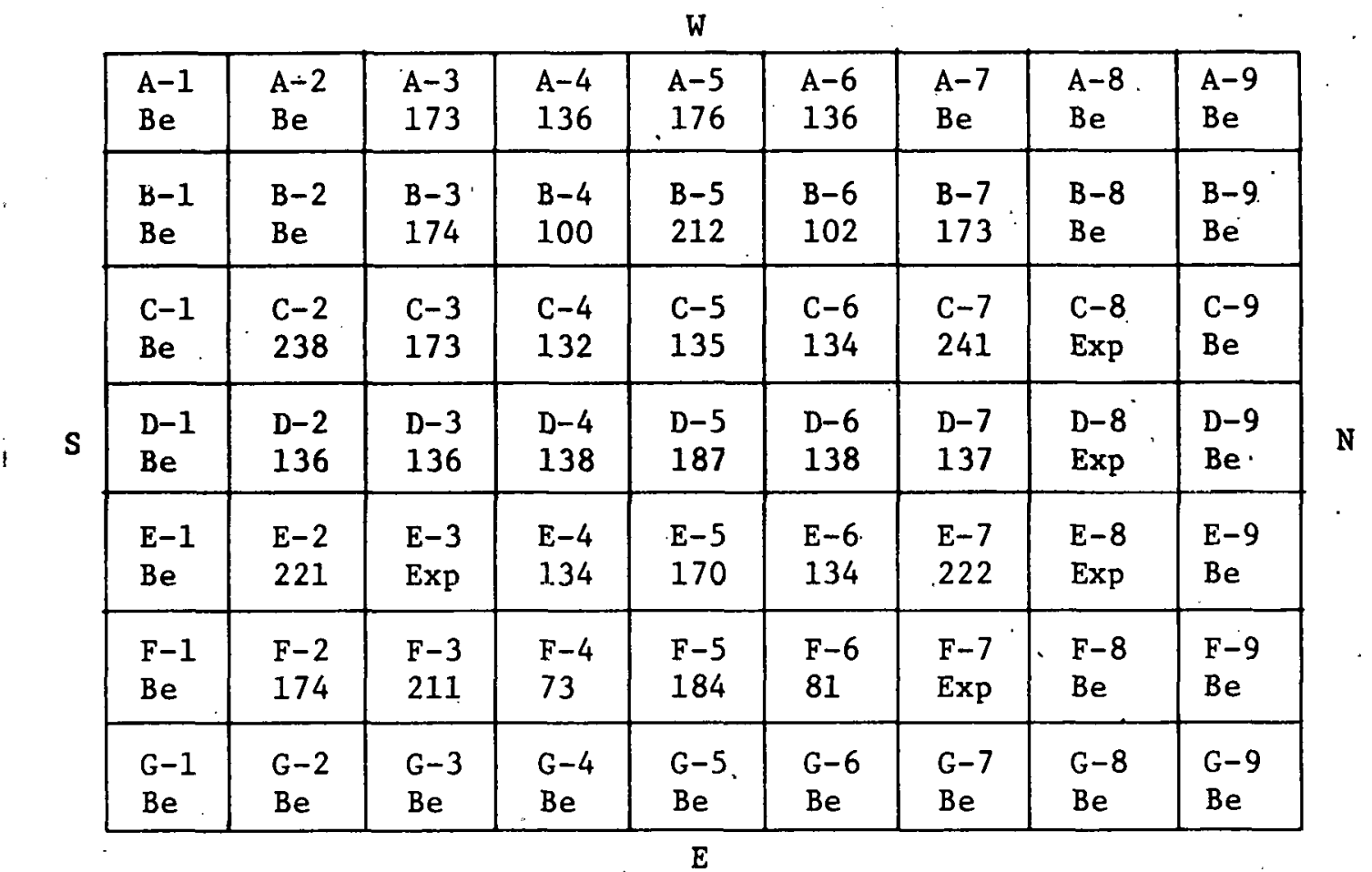

Fig. 8. Fuel element loadings ( $g$ of ${ }^{235} \mathrm{U}$ ). Shim rod position was $0.409 \mathrm{~m}$ - distance from horizontal midplane of core to center line of cadmium in shim rod.

and E-7 positions. Dosimeter packages were inserted into central holes in the capsules and into the southeast corners of the aluminum core pieces of the $C-3$ and E-3 facilities. The ORR was then operated at $1 \%$ power for $10 \mathrm{hr}$. while in the core configuration shown in Fig. 11.

Unfortunately, the core was not loaded in the precise configuration planned for irradiation tests; a beryllium element was in position F-8 instead of a fuel element. VENTURE calculations run to determine the effect of this difference indicated that a fuel element in F-8 causes only 


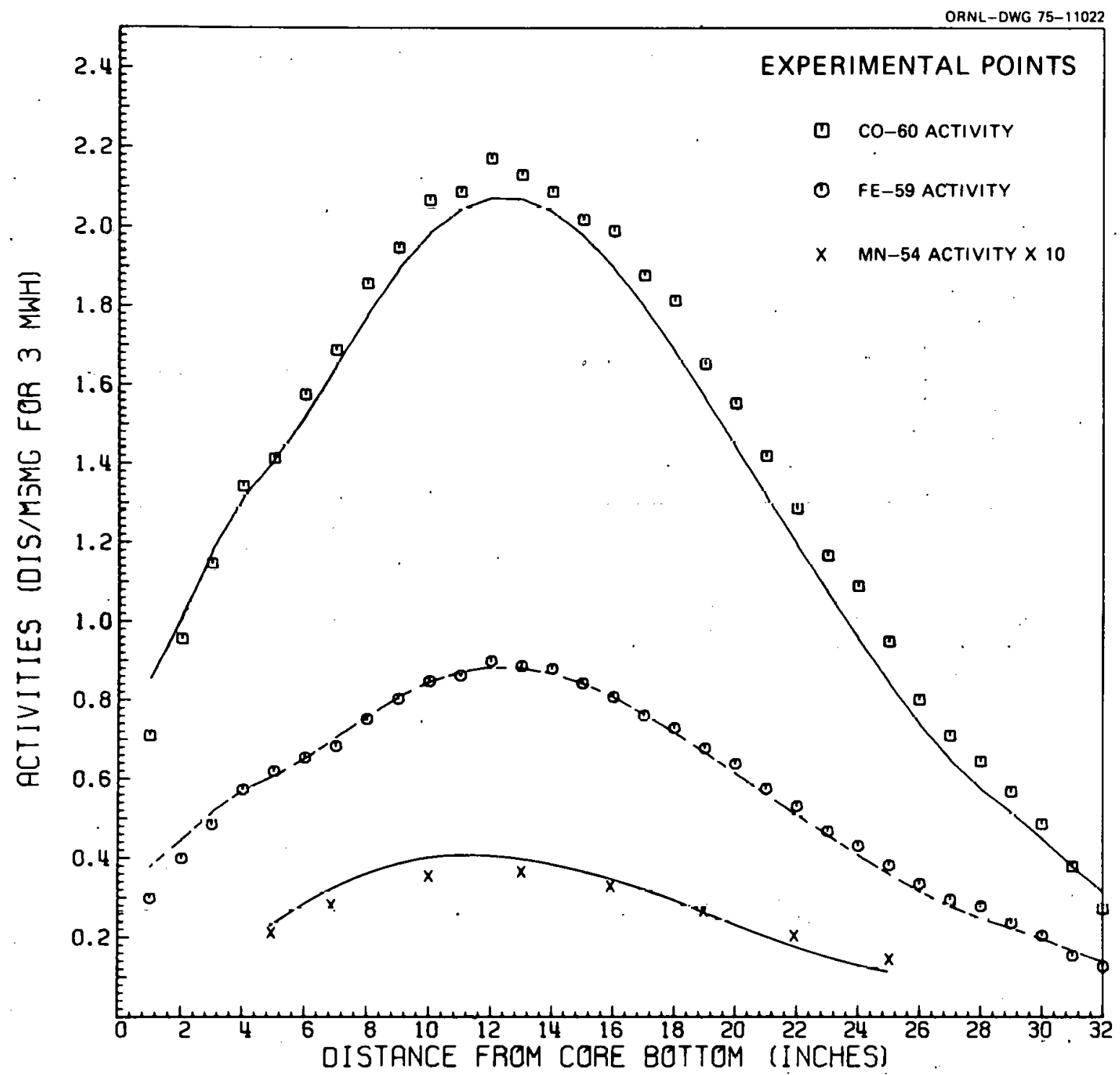

Fig. 9. Experimental and calculational activity profiles for B-2 beryllium element ( 1 in. $=25.4 \mathrm{~mm}$ ).

minor changes in the E-3, C-3, and E-5 fluxes, and the flux increases by about $5 \%$ in $\mathrm{E}-7$.

The total flux and damage flux for the four positions, as determined experimentally, are shown in Fig. 12. The flux increased about $15 \%$ in the southeast corner of the E-3 facility and about $20 \%$ in the southeast corner of the C-3 facility from previous measurements for the $O G-1$ and the $O F-1$ experiments. These increases were caused by the altered fuel loading in 


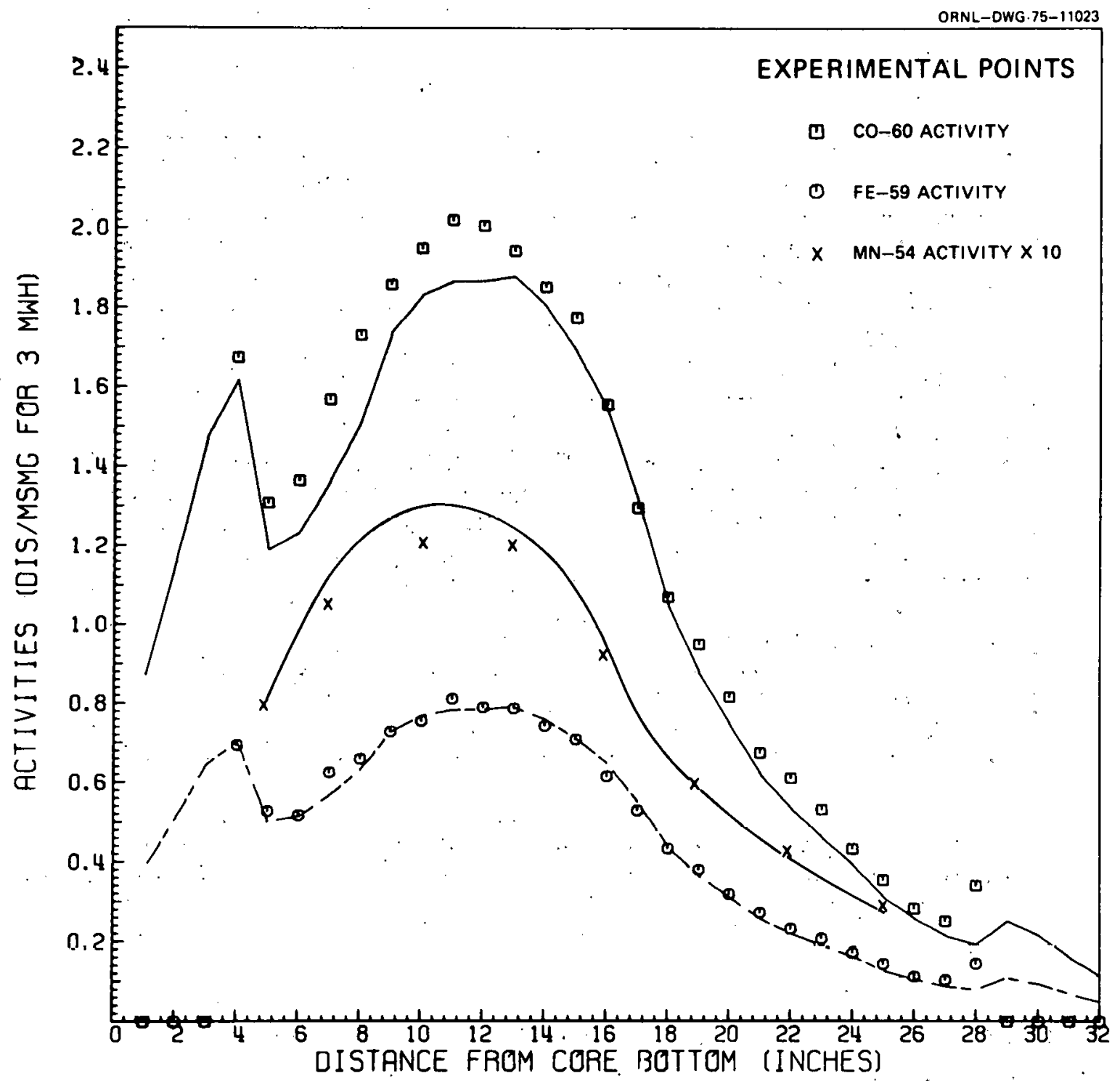

Fig. 10. Experimental and calculational activity profiles for C-6 fuel element ( $1 \mathrm{in}$. $=25.4 \mathrm{~mm})$. 
ORNL-DWG 76-5732

$$
\begin{aligned}
& \text { Be - Beryllium element } \\
& \text { Exp - Experiment or } \\
& \text { experimental facility }
\end{aligned}
$$

\begin{tabular}{|c|c|c|c|c|c|c|c|c|}
\hline $\begin{array}{l}\mathrm{A}-1 \\
\mathrm{Be}\end{array}$ & $\begin{array}{l}A-2 \\
\text { Exp }\end{array}$ & $\begin{array}{l}A-3 \\
187\end{array}$ & $\begin{array}{l}A-4 \\
243\end{array}$ & $\begin{array}{l}A-5 \\
187\end{array}$ & $\begin{array}{l}\text { A-6 } \\
197\end{array}$ & $\begin{array}{l}\mathrm{A}-7 \\
\mathrm{Be}\end{array}$ & $\begin{array}{l}\mathrm{A}-8 \\
\mathrm{Be}\end{array}$ & $\begin{array}{l}\mathrm{A}-9 \\
\mathrm{Be}\end{array}$ \\
\hline $\begin{array}{l}\mathrm{B}-1 \\
\mathrm{Be}\end{array}$ & $\begin{array}{l}\dot{B}-2 \\
145\end{array}$ & $\begin{array}{l}B-3 \\
142\end{array}$ & $\begin{array}{l}\text { B-4 } \\
105\end{array}$ & $\begin{array}{l}B-5 \\
185\end{array}$ & $\begin{array}{l}B-6 \\
105\end{array}$ & $\begin{array}{l}B-7 \\
144\end{array}$ & $\begin{array}{l}\text { B-8 } \\
\mathrm{Be}\end{array}$ & $\begin{array}{l}\text { B-9 } \\
\mathrm{Be}\end{array}$ \\
\hline $\begin{array}{l}\mathrm{C}-\mathrm{I} \\
\mathrm{Be}\end{array}$ & $\begin{array}{l}C-2 \\
240\end{array}$ & $\begin{array}{l}C-3 \\
\text { Exp }\end{array}$ & $\begin{array}{l}\text { C-4 } \\
142\end{array}$ & $\begin{array}{l}C-5 \\
151\end{array}$ & $\begin{array}{l}\text { C-6 } \\
140\end{array}$ & $\begin{array}{l}C-7 \\
240\end{array}$ & $\begin{array}{l}C-8 \\
138\end{array}$ & $\begin{array}{l}\mathrm{C}-9 \\
\mathrm{Be}\end{array}$ \\
\hline $\begin{array}{l}\mathrm{D}-1 \\
\mathrm{Be}\end{array}$ & $\begin{array}{l}D-2 \\
150\end{array}$ & $\begin{array}{l}D-3 \\
154\end{array}$ & $\begin{array}{l}D-4 \\
138\end{array}$ & $\begin{array}{l}D-5 \\
154\end{array}$ & $\begin{array}{l}D-6 \\
138\end{array}$ & $\begin{array}{l}\text { D-7 } \\
158\end{array}$ & $\begin{array}{l}\text { D-8 } \\
\text { Exp }\end{array}$ & $\begin{array}{l}\mathrm{D}-9 \\
\mathrm{Be}\end{array}$ \\
\hline $\begin{array}{l}\mathrm{E}-1 \\
\mathrm{Be}\end{array}$ & $\begin{array}{l}\text { E-2 } \\
137\end{array}$ & $\begin{array}{l}\text { E-3 } \\
\text { Exp }\end{array}$ & $\begin{array}{l}\text { E-4 } \\
141\end{array}$ & $\begin{array}{l}\text { E-5 } \\
\text { Exp }\end{array}$ & $\begin{array}{l}\text { E-6 } \\
140\end{array}$ & $\begin{array}{l}\text { E-7 } \\
\text { Exp }\end{array}$ & $\begin{array}{l}E-8 \\
140\end{array}$ & $\begin{array}{l}\mathrm{E}-9 \\
\mathrm{Be}\end{array}$ \\
\hline $\begin{array}{l}\mathrm{F}-1 \\
\mathrm{Be}\end{array}$ & $\begin{array}{l}F-2 \\
239\end{array}$ & $\begin{array}{l}F-3 \\
196\end{array}$ & $\begin{array}{l}F-4 \\
80\end{array}$ & $\begin{array}{l}F-5 \\
198\end{array}$ & $\begin{array}{l}F-6 \\
82\end{array}$ & $\begin{array}{l}F-7 \\
239\end{array}$ & $\begin{array}{l}\mathrm{F}-8 \\
\mathrm{Be}\end{array}$ & $\begin{array}{l}\mathrm{F}-9 \\
\mathrm{Be}\end{array}$ \\
\hline $\begin{array}{l}\mathrm{G}-1 \\
\mathrm{Be}\end{array}$ & $\begin{array}{l}\mathrm{G}-2 \\
\mathrm{Be}\end{array}$ & $\begin{array}{l}\mathrm{G}-3 \\
\mathrm{Be}\end{array}$ & $\begin{array}{l}\mathrm{G}-4 \\
\mathrm{Be}\end{array}$ & $\begin{array}{l}\text { G-5 } \\
\mathrm{Be}\end{array}$ & $\begin{array}{l}\mathrm{G}-6 \\
\mathrm{Be}\end{array}$ & $\begin{array}{l}\mathrm{G}-7 \\
\mathrm{Be}\end{array}$ & $\begin{array}{l}\mathrm{G}-8 \\
\mathrm{Be}\end{array}$ & $\begin{array}{l}\mathrm{G}-9 \\
\mathrm{Be}\end{array}$ \\
\hline
\end{tabular}

POOL

Fig. 11. Fuel element 1oadings ( $g$ of ${ }^{235} \mathrm{U}$ ). Shim rod position was $0.476 \mathrm{~m}$-distance from horizontal midplane of core to center line of cadmium in shim rod.

the core. The average maximum total flux for the four tacilities is $1.04 \times$ $10^{15}$ neutrons $\mathrm{cm}^{-2} \mathrm{sec}^{-1}$, and the fluxes in all. four facilities are within $15 \%$ of the averagc. The constanta $f$ and $k$ for each of the four facilities are :
$\underline{\mathrm{f}} \quad \underline{\mathrm{k}}$
C3 - southeast corner
$0.1969 \quad 0.0204$
E3 - southeast corner
0.1973
0.0206
E5 - center
0.1719
0.0204
E7 - center
0.1657
0.0201 


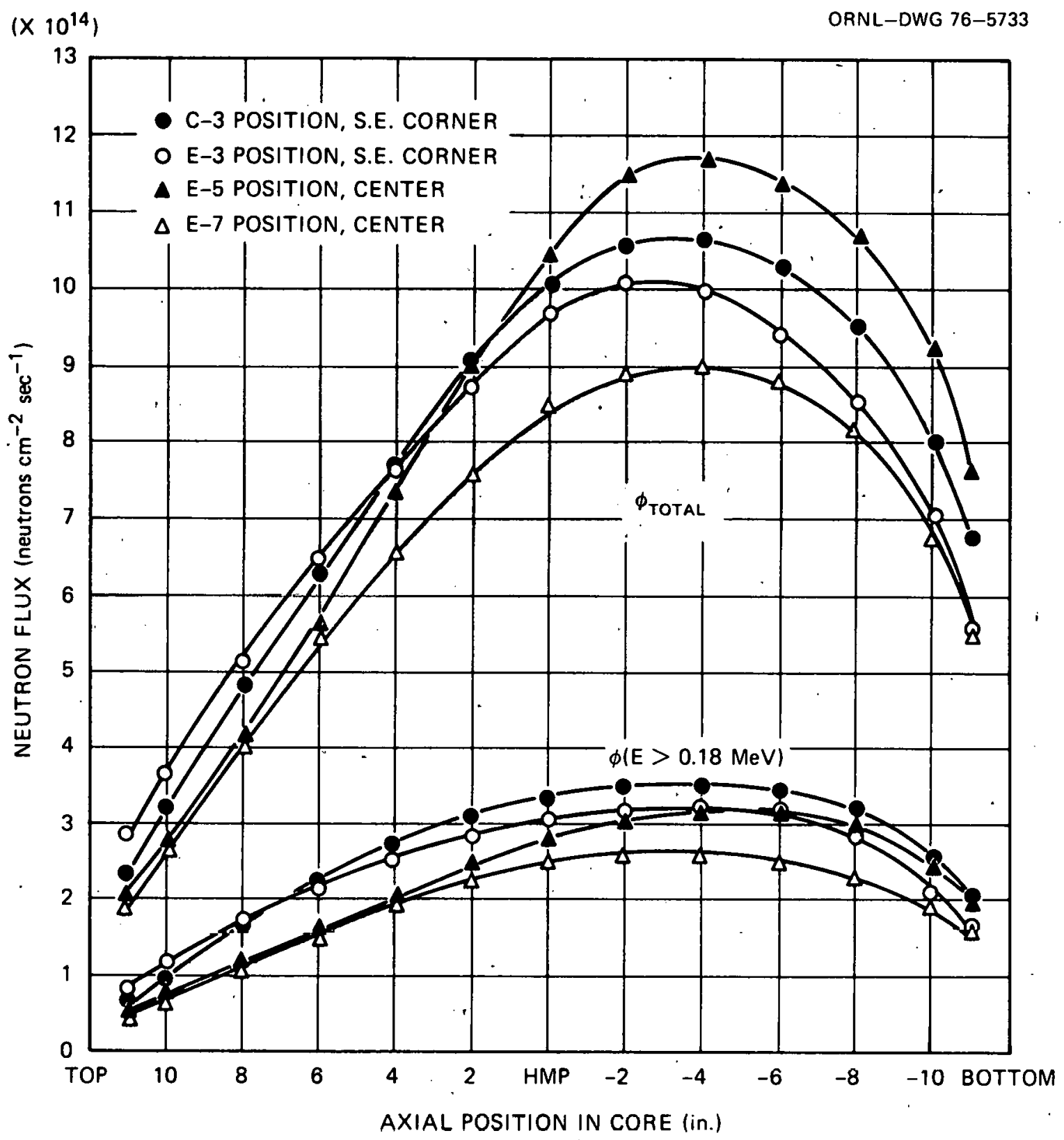

Fig. 12. Fluxes in the $\mathrm{C}-3, \mathrm{E}-3, \mathrm{E}-5$, and E-7 irradiation facilities (1 in. $=25.4 \mathrm{~mm}$ ). 


\section{Poolside Position P4 Flux Map and TeGen-1}

The TeGen-1 capsule, which was irradiated in the $\mathrm{P} 4 \mathrm{~A}$ poolside facility of the ORR for the Molten-Salt Reactor Program, contained three fuel pins composed of Hastelloy N, 304 stainless steel, and Inconel 601, each containing ${ }^{233} \mathrm{U}$ fuel salt. The objective of the experiment was to determine the effects of fission product penetration, particularly that of tellurium, on these metals. Neutronics support was required to determine the ${ }^{233} \mathrm{U}$ fission rate and tellurium generation rate for each fuel pin.

The TeGen-1 capsule position in the P4A track was changed during irradiation to maintain specified operating temperatures for each of the three fuel pins. Consequently, neutron fluxes as a function of position in $\mathrm{P} 4 \mathrm{~A}$ were needed to estimate reaction rates, so a flux-monitoring facility was constructed and loaded into the adjacent poolside position $\mathrm{P} 4 \mathrm{~B}$.

Aluminum tubes containing monitor materials were inserted into an aluminum-iron capsule simulating the TeGen-1 capsule, and the capsules were irradiated at various positions for specified times in the $\mathrm{P} 4 \mathrm{~B}$ poolside facility. The ${ }^{233} \mathrm{U}$ flssion rates in TeGen-1 were then estimated from the induced activities of these monitor materials. Unfortunately, while the flux map was being made, a large gas-filled experiment was in the P5 position. However, the experiment in $P 5$ was removed after the f1rst week of TeGen-1 operation, and one position in the $\mathrm{P} 4 \mathrm{~B}$ track was remapped to get an estimate of the perturbation caused by the experiment. From these mappings, the ${ }^{233} \mathrm{U}$ fisston rate for the aluminum-1ron capsule in $\mathrm{P} 4 \mathrm{~B}$ could be determined and an estimate made for $\mathrm{P} 4 \mathrm{~A}$. The estimated ${ }^{23} \mathrm{U}$ fission rates for both capsules in $\mathrm{P} 4 \mathrm{~A}$ and $\mathrm{P} 4 \mathrm{~B}$ are plotted vs track position in Fig. 13 .

Calculatione were then performed using the neut.rnn transport code XSDRNPM to determine the relative flux perturbations caused by the aluminum-iron capsule and the TeGen-1 capsule. The calculations indicated that the TeGen-1 capsule decreased the flux about $35 \%$ more than the aluminumiron capsule. The flux depressions for the aluminum-iron and the TeGen-1 capsules were 25.4 and $52.0 \%$ respectivley. The reaction rate curves in Fig. 13 for the aluminum-iron capsule should be about $35 \%$ lower for the TeGen-1 capsule. 


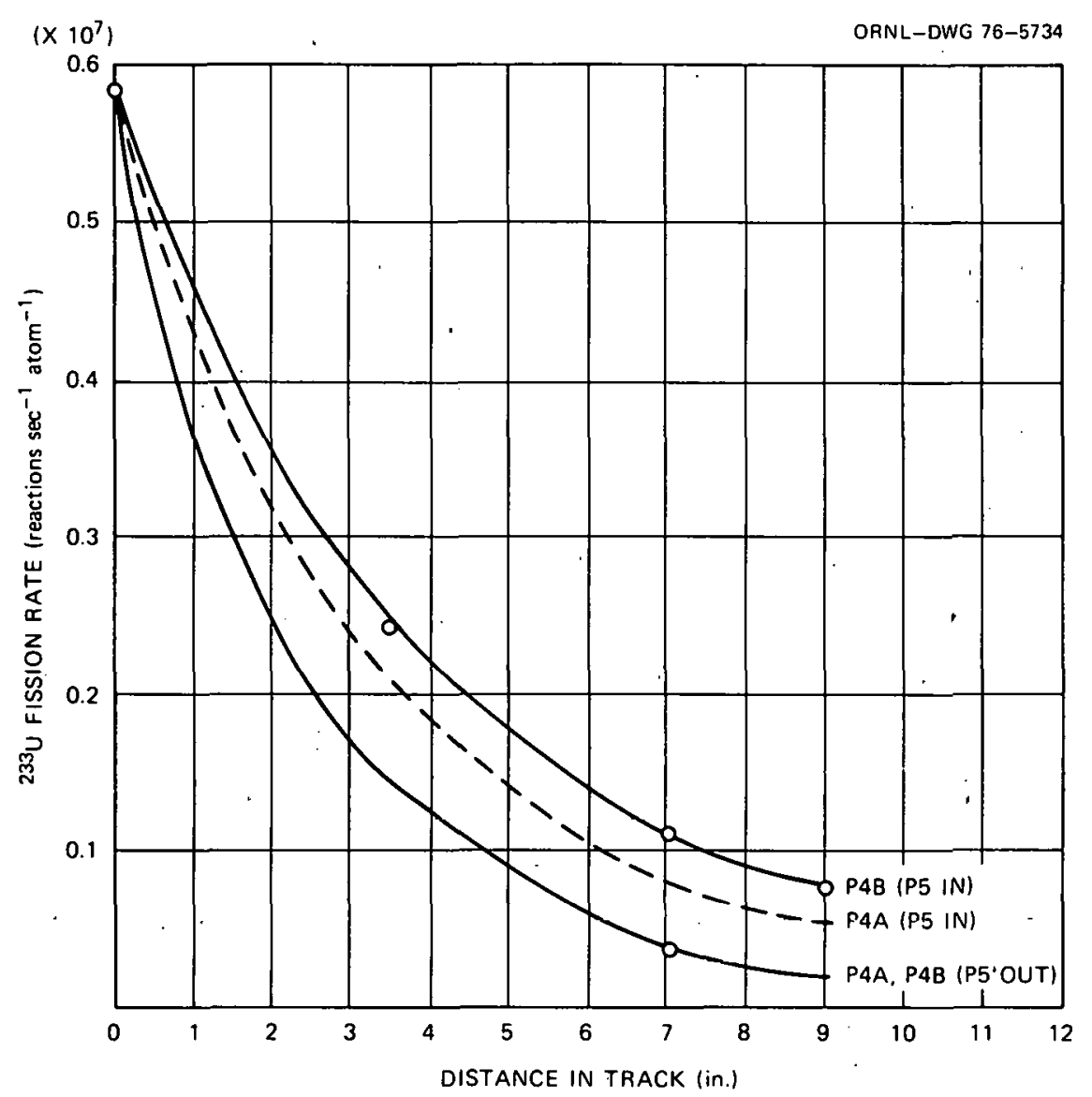

Fig. 13. ${ }^{233} \mathrm{U}$ fission rate in $\mathrm{P} 4 \mathrm{~A}$ and $\mathrm{P} 4 \mathrm{~B} 50.8 \mathrm{~mm}$ below core midplane (1 in. $=25.4 \mathrm{~mm}$ ).

Various dosimeter wires were also contained within the TeGen-1 capsule. When the capsule was disassembled, these wires were recovered and the induced activities for the following reactions measured:

$$
{ }^{59} \mathrm{Co}(\mathrm{n}, \gamma){ }^{60} \mathrm{Co} \cdot \quad{ }^{54} \mathrm{Fe}(\mathrm{n}, \mathrm{p}){ }^{54} \mathrm{Mn} . \quad{ }^{58} \mathrm{Fe}(\mathrm{n}, \gamma){ }^{59} \mathrm{Fe}
$$

The activities of these monitors indicated that the ${ }^{23}{ }^{3} \mathrm{U}$ fission rate was $40 \%$ less than' that estimated by the aluminum-iron capsule flux, mapping, which agrees closely with the perturbation calculations.

Based on the above analysis, full-power fission rates (fissions per sec per atom) for the upper, middle, and lower fuel pins are $2.93 \times 10^{-9}$, $3.23 \times 10^{-9}$, and $2.90 \times 10^{-9}$ respectively. The tellurium production rates for the three fuel pins are given in Ref. 9 . 
The ORR-232 Experiment in the P5 Poolside Position

The ORR-232 experiment was one of a series of experiments designed to test the creep propertles of modified Hastelloy $\mathrm{N}$ under irradiation. The experimental capsules, helium-filled aluminum boxes containing horizontally mounted Hastelloy specimens, are irradiated in the P5 poolside position of the ORR. The ORR-232 experiment was irradiated from May 10, 1975 , to July 15, 1975, to accumulate 42,252 MWr nf reactor operation. Flux monitors were included in ORR-232 for later determination of neutron and helium production rates in the Hastelloy specimens.

Seventeen 302 stainless steel monitors doped with $0.0804 \%$ cobalt were placed at the base of the Hastelloy specimen, which was about $84 \mathrm{~mm}$ from the aluminum face of the poolside. At the end of the ORR-232 irradiation, the flux monitors were recovered and the induced activities of ${ }^{59} \mathrm{Fe},{ }^{54} \mathrm{Mn}$, and ${ }^{60}$ Co measured for each monitor.

A neutron transport XSDRNPM calculation modeling the experimental geometry was performed to obtain neutron energy spectra. With these spectra the neutron-flux magnitudes required to induce the activities were calculated. The total flux obtained from these calculations is presented in Fig. 14, along with the total flux indicated by the indured artivities of ${ }^{54} \mathrm{Mn}$, ${ }^{5 y} \mathrm{Fe}$, and ${ }^{60} \mathrm{Co}$. As may be seen, there is good agreement between the total fluxes that are indicated by the three induced activities. This is an indication that the selected neutron-flux spectrum is reasonably correct. For this spectrum the fraction of the total flux above energies of $1.00,0.183$, and $0.111 \mathrm{MeV}$ are $0.115,0.199$, and 0.212 respectively. The factors $f$ and $k$ for this spectrum are 0.3957 and 0.0333 respectively.

From the XSDRNPM model of the ORR-232 experiment, there is a $16 \%$ inwiabs lis the total flus from the base to the fruml of the specimen and a $29 \%$ increase in the fraction of the flux above $1.0 \mathrm{MeV}$ over the same distance. However, the change in the low-energy neutrons across the specimen is only about $2 \%$. Since most of the helium is produced from the two-step ${ }^{58} \mathrm{Ni}(\mathrm{n}, \gamma){ }^{59} \mathrm{Ni}(\mathrm{n}, \alpha)$ reaction and the ${ }^{10} \mathrm{~B}(\mathrm{n}, \alpha)$ reaction, which are primarily low-energy-neutron-induced reactions, the helium production across the specimen can be assumed constant. 
ij.

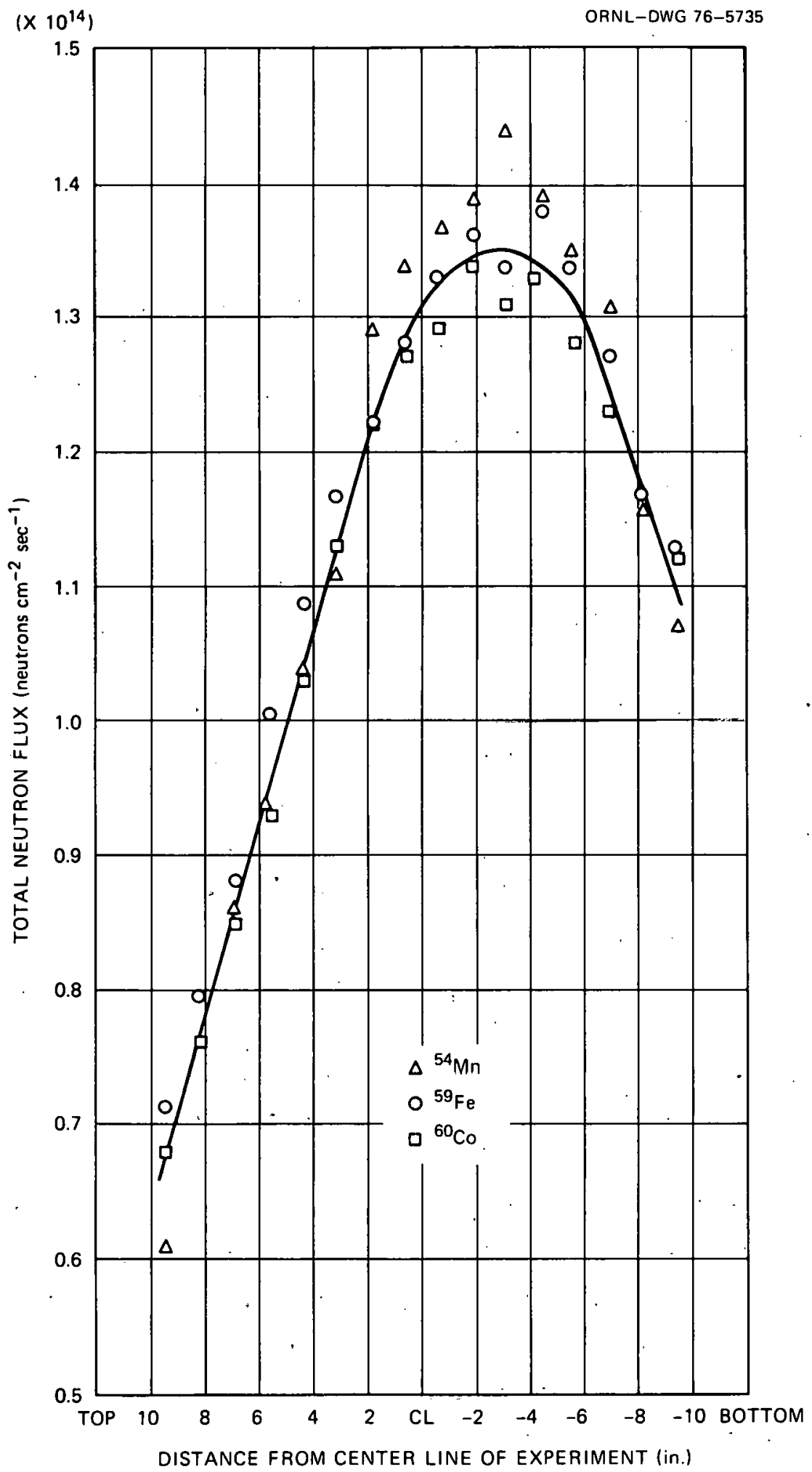

Fig. 14. Total neutron fluxes for the ORR-232 experiment $(1 \mathrm{in} .=25.4 \mathrm{~mm})$. 


\section{Neutron Fluxes in the ORR Poolside Facilities}

The poolside facilities are the most accessible irradiating facilities in the ORR. Experimental capsules can be closely monitored and inserted or removed at any time. The poolside tracks into which the capsules are placed are movable, and the capsules can be moved closer or farther away from the core to achieve desired operating temperatures. The disadvantages of the ORR poolside are lower neutron flux levels than the core, steep flux gradients, flux perturbations caused by the capsule and surrounding experimental capsules, and less knowledge of the neutron flux levels in the facilities.

Presently, flux information for poolside experiments is obtained from dosimeters that are placed within the capsules. Upon completion of the experiments, the induced activities in the dosimeters are analyzed to determine neutron fluxes or reaction rates. An accurate computational model of the neutron fluxes in the poolside would be of assistance in these analyses. A neutron-flux model for the poolside could be developed using a two-dimensional discrete-ordinates transport code ${ }^{10}$ such as DOT III. The development of this model would be coupled with a flux mapping experiment of the poolside to test the adequacy of the model and for use as future reference.

However, rough estimates of poolside neutron fluxes are frequentiy requested. An average neutron flux profile for the poolside facility is presented in Fig. 15 vs distance from the aluminum face of the poolside. (An aluminum wall separates the core elements from the poolside. The poolside tace of the wall is about $25.4 \mathrm{~mm}$ from the core elements and about $31.8 \mathrm{~mm}$ from the start of the poolside tracks.) The factor $f$ is also plotted in the figurc. The factor $k$ ie taken as zero. These fluxes were obtained from a one-dimensional spherical-geometry transport calculation that modeled the ORR core and poolside. The calculated flux spectra and magnitudes compare favorably with the dosimeter analyses of the poolside position P-4 mapping, TeGen-1, and the ORR-232 experiment. More information on poolside fluxes and the variation in the fluxes for the different poolside facilities is available in Ref. 11. 
1. .

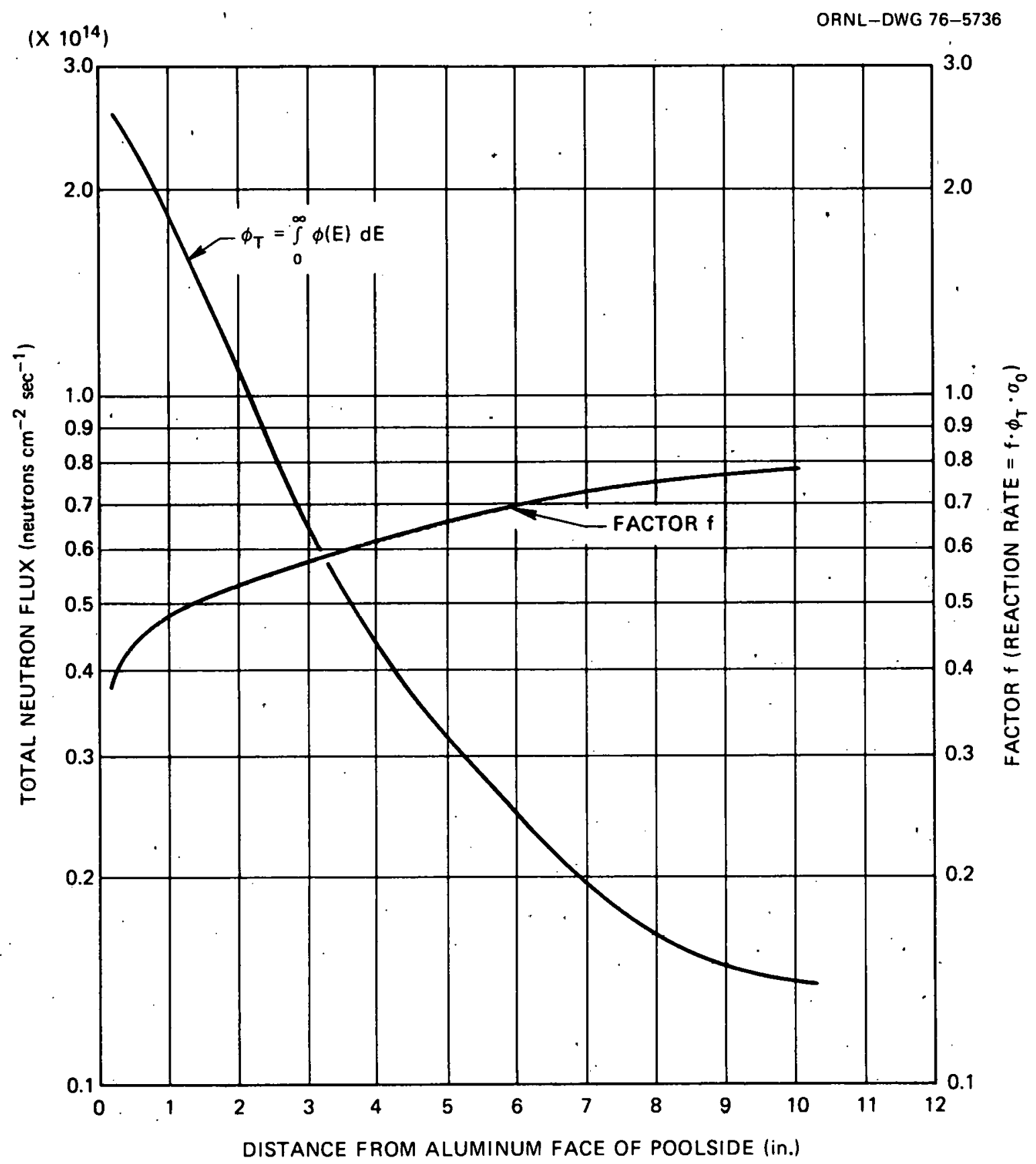

Fig. 15. Calculated. unperturbed neutron fluxes in the ORR poolside (1 in. $=25.4 \mathrm{~mm}$ ). 
Neutron Fluxes in the Hydraulic Tube Facility

The hydraulic tube factlity of the ORR, currently located in the D8 core lattice position, consists essentially of an aluminum core piece with several water-filled axial holes. There are five experimental "rabbit" tubes in the facility numbered 21 through 25, each of which can accommodate up to five rabbits at any one time. A top view of the facility is given in Fig. 16 along with the five axial positions that the rabbit capsules could occupy in each tube. The rabbit capsules are about $63.5 \mathrm{~mm}$ long and about $12.7 \mathrm{~mm}$ in outside diameter. The hydraulic tube is very convenient for irradiating small samples for several minutes to several days.

The neutron fluxes in the facility are very dependent on the composition of the surrounding core pieces. The neutron fluxes for two different core configurations (shown in Figs. 8 and 11) near the hydraulic tube were calculated with the VENTURE model. Neutron fluxes above 0.18 $\mathrm{MeV}$ for the two configurations are given in Fig. 17. For configuration I (Fig. 8), two calculations were done: one for zero days into the fuel cycle when the cadmium portion of the shim rods extended down to $25.4 \mathrm{~mm}$ above the horizontal midplane and the other for seven days into the cycle when the cadmium portion of the shim rod extended down to $152 \mathrm{~mm}$ above the horizontal midplane. The movement of the shim rods caused the appreciable shift in the axial flux profile.

A rabbit. capsule containing neutron dosimeters was irradiated for $10 \mathrm{hr}$ in axial position 3 of the HT-25 tube on day 21 of cycle 125, and the induced activities in the monitors were analyzed to produce measured neutron fluxes. Since the core elements near the hydraulic tube of cycle 125 are similar to those of core configuration II calculated by VENTURE, the measured fluxes were compared with calculated fluxes and are presented in Fig. 18. There is favorable agreement between the measured and calculated fluxes.

No dosimeter experiments were performed for the other rabbit tubes. However, estimates of reaction rates in these tubes can be male from the calculated fluxes of the VENTURE model. The calculated total fluxes for each of the two core configurations for the hydraulic tube facility are 


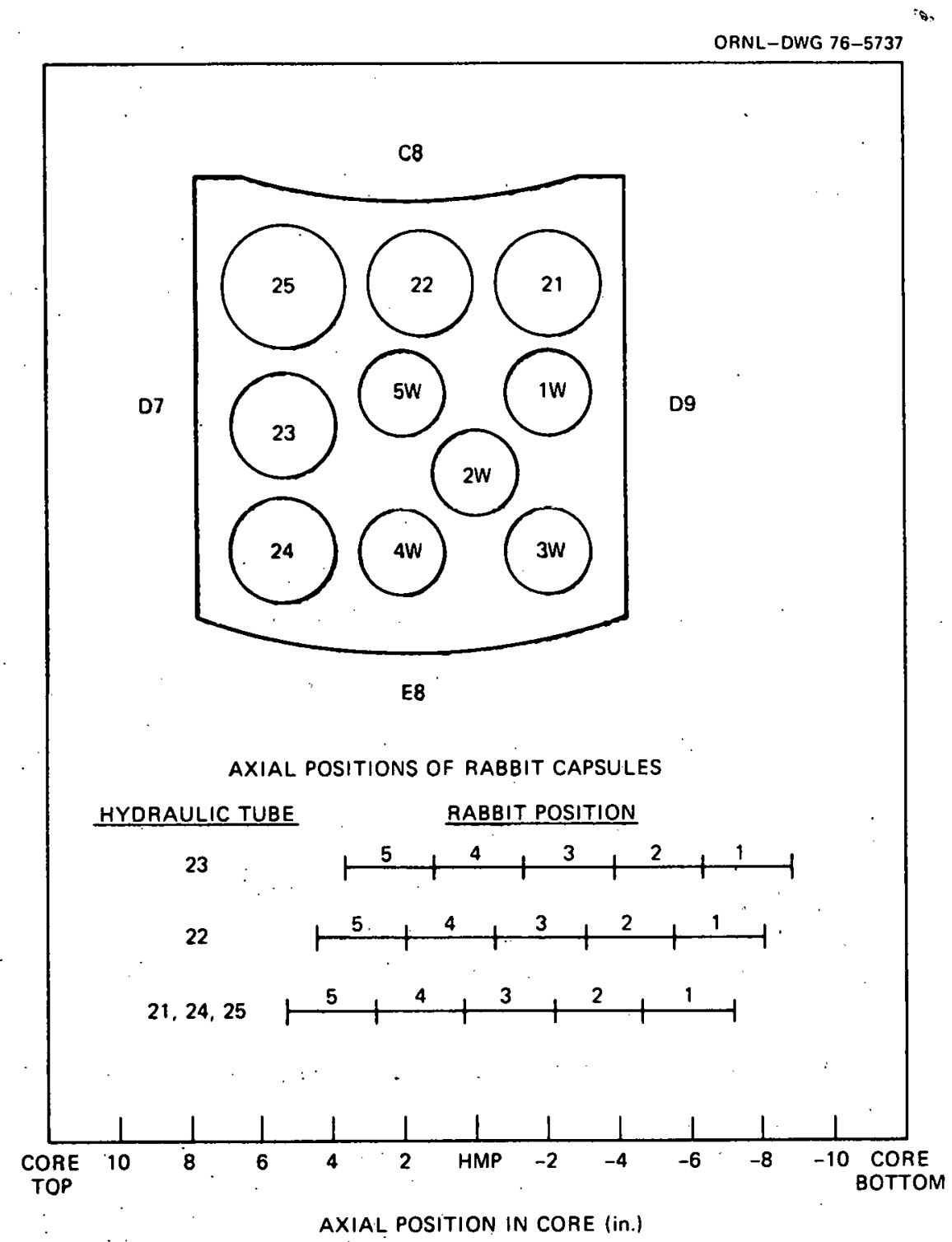

Fig. 16. ORR hydraulic tube facility and axial positions of rabbits (1 in. $=25.4 \mathrm{~mm}$ ): 


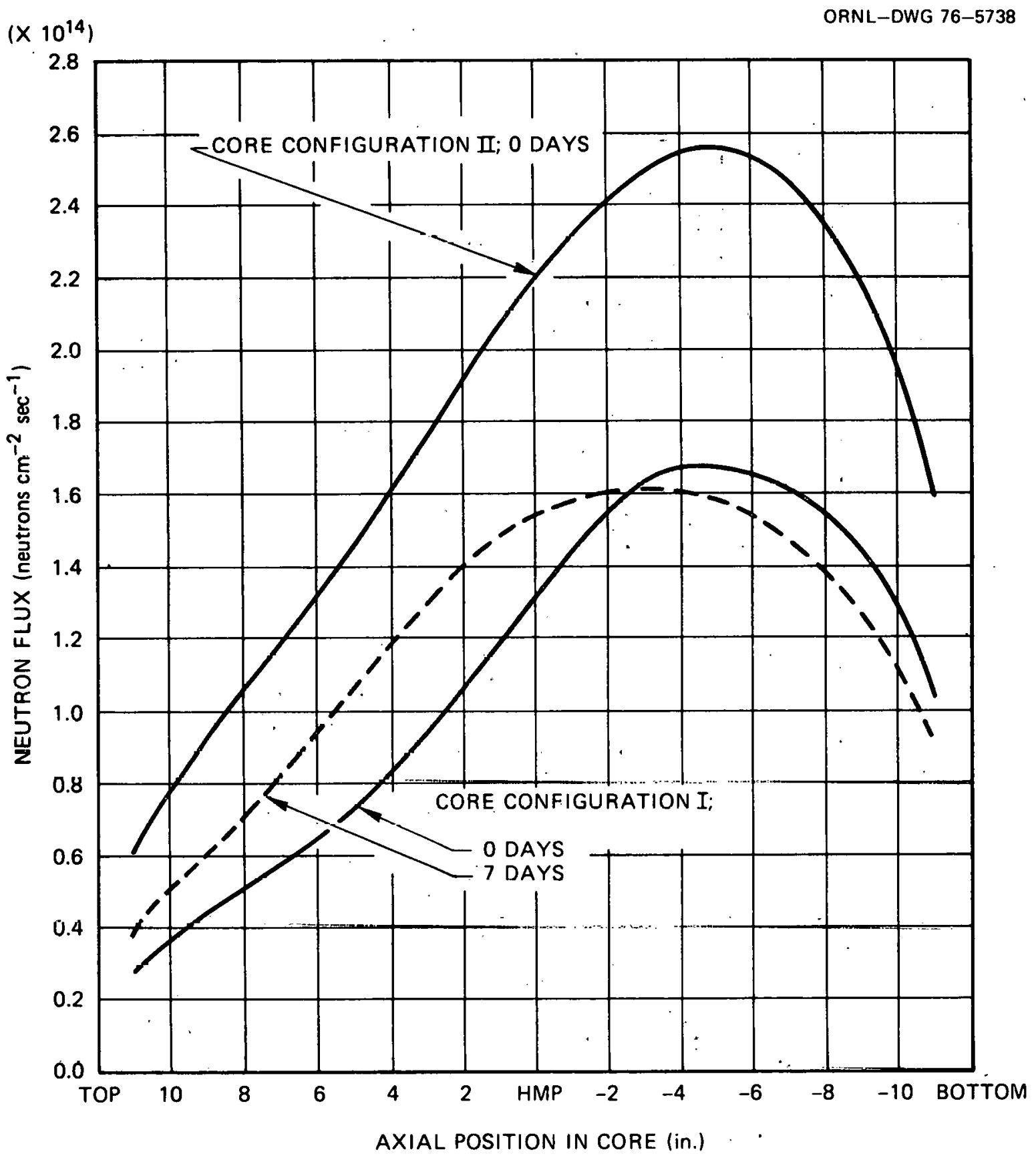

Fig. 17. Calculated axial profiles of neutron flux above $0.18 \mathrm{MeV}$ in the HT-25 tube of the ORR hydraulic facility ( 1 in. $=25.4 \mathrm{~mm}$ ). 


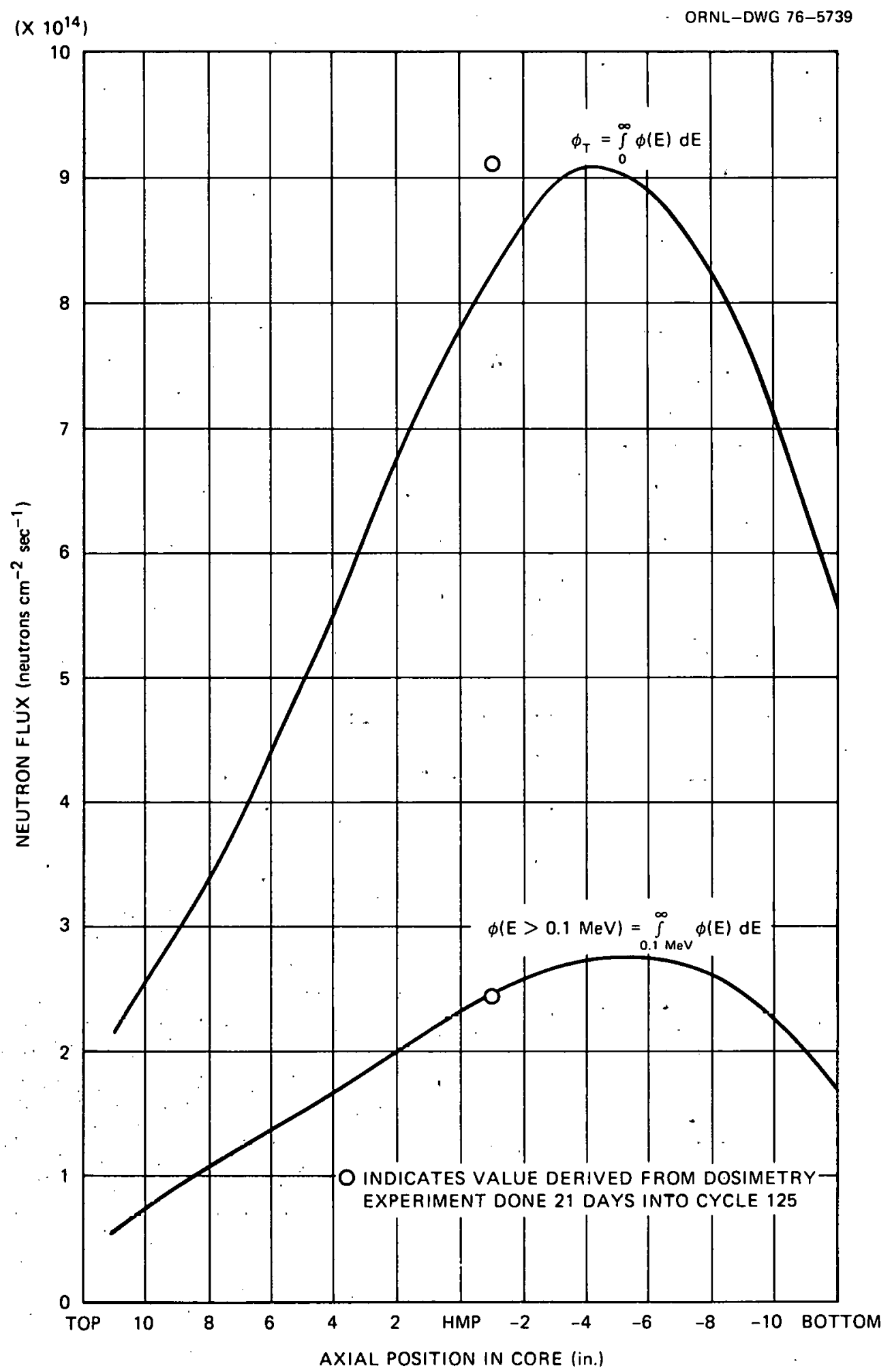

Fig. 18. Calculated neutron-flux axial profiles for the HT-25 tube of the ORR hydraulic tube facllity at start of cycle with core configuration similar to that of cycle 125 ( 1 in. $=25.4 \mathrm{~mm}$ ). 
given in Table 3. The factors $f$ and $k$ to be used with these fluxes are 0.3154 and 0.0177 respectively.

Table 3. Calculated total neutron flux

( $10^{14}$ neutrons $\mathrm{cm}^{-2} \mathrm{sec}^{-1}$ ) in the

hydraulic tube facility for

various core configurations

\begin{tabular}{|c|c|c|c|c|c|}
\hline \multirow{2}{*}{$\begin{array}{l}\text { Hydraulis } \\
\text { tube }\end{array}$} & \multicolumn{5}{|c|}{ Axial rabbit position } \\
\hline & 5 & 4 & 3 & $\underline{2}$ & 1 \\
\hline Core & config & cation & $I: z e$ & days & \\
\hline $\begin{array}{l}\text { HT-21 } \\
\text { HT-22 } \\
\text { HT-23 } \\
\text { HT-24 } \\
\text { HT-25 }\end{array}$ & $\begin{array}{l}2.93 \\
3.61 \\
4.41 \\
3.57 \\
3.53\end{array}$ & $\begin{array}{l}3.98 \\
4.84 \\
5.82 \\
4.90 \\
4.94\end{array}$ & $\begin{array}{l}4.65 \\
5.58 \\
6.55 \\
5.82 \\
5.93\end{array}$ & $\begin{array}{l}5.32 \\
6.16 \\
6.87 \\
6.76 \\
6.96\end{array}$ & $\begin{array}{l}5.36 \\
6.01 \\
6.43 \\
6.84 \\
7.08\end{array}$ \\
\hline
\end{tabular}

Core configuration $\mathrm{I}: 7$ days

$\begin{array}{llllll}\text { HT-21 } & 3.99 & 4.96 & 5.39 & 5.57 & 5.33 \\ \text { HT-22 } & 4.83 & 5.83 & 6.19 & 6.17 & 5.75 \\ \text { HT-23 } & 5.67 & 6.58 & 6.83 & 6.55 & 5.90 \\ \text { HT-21 } & 4.76 & 6.111 & 6.44 & 6.78 & 6.50 \\ \text { HT-25 } & 4.90 & 6.22 & 6.80 & 1.07 & 6.78\end{array}$

Core configuration IT. zero days

$\begin{array}{llllll}\text { HT-21 } & 5.03 & 6.37 & 7.13 & 7.76 & 7.67 \\ \text { HT-22 } & 5.79 & 7.23 & 7.98 & 8.40 & 8.06 \\ \text { H'l-23 } & 6.45 & 7.87 & 8.50 & 8.56 & 7.93 \\ \text { HT-24 } & 5.34 & 6.83 & 7.70 & 8.43 & 8.34 \\ \text { HT-25 } & 5.50 & 7.17 & 8.18 & 9.07 & 9.00\end{array}$

OBSERVATIONS

Several observations can be made from the preceding summary of neutron fluxes and neutron-induced reaction rates in experimental facilities of the ORR. 
1. The neutron fluxes in a particular experimental facility are affected to varying degrees by changes in the ORR core configuration. Capsules in the poolside and outer core lattice positions are most sensitive to core configuration changes, and flux variations as 1 arge as $\pm 100 \%$ are not unusual.

2. The axial flux profile in every facility changes throughout the fuel cycle due to shim rod movement. The axial position of the maximum neutron flux shifts about 10 to $12 \mathrm{~cm}$ during the fuel cycle with little change in maximum flux magnitude. However, fluxes near the ends of the fuel elements change by as much as $\pm 30 \%$ during the fuel cycle.

3. The neutron fluxes in a given facility are influenced by the composition of the capsule to be irradiated in that facility and by the composition of capsules in nearby facilities. Neutron-induced reaction rates for capsules in a given facility have been observed to change by as much as $50 \%$ due only to changes in capsule composition. Also flux perturbations ranging from 10 to $60 \%$ have been observed in some facilities when capsules were removed from nearby facilities.

Because these and other factors so strongly influence neutron fluxes in ORR facilities, it is not possible to rigidly define the neutronic conditions for a given irradiation facility in the ORR. Each experiment must be treated individually. Calculations must be done and/or neutron dosimetry experiments performed to accurately determine neutronic parameters for evaluation of irradiation experiments. At this time, the status of these techniques in regards to the approximate accuracy of the derived neutron fluxes is summarized below.

1. Neutron fluxes derived solely on the basis of calculations are accurate to within $\pm 20 \%$ for facilities in the ORR core. In the poolside, no accurate calculational techniques have been developed.

2. Dosimetry experiments are essential at the present time for poo1side experiments. The error in the derived neutron fluxes from dosimetry experiments can be reduced by increasing the number of dosimeter materials. In practice, fluxes derived from dosimeter data for the poolside are accurate to within $15 \%$. In the core, dosimetry experiments can be combined with calculations to yield accuracies of about $10 \%$. 


\section{ACKNOWLEDGMENTS}

Many ORNL people have contributed to this report. In particular, the authors wish to express their thanks to G. W. Cunningham III, T. B. Fowler, C. B. Gaither, N. M. Greene, S. S. Hurt III, R. W. Knoll, H. A. Parker, M. E. Pruitt, D. L. Reed, 'T. M. Sims, J. H. Swanks, D. R.'Vondy, and Margaret Wilson.

\section{REFERENCES}

1. T. P. Hamrick and J. H. Swanks, The Oak Ridge Research Reactor - A Furictional Description, ORNL-4169 (September 1968).

2. Sand II, A Computer Automated Iteration Method for Neutron Flux Spectra Determination for Foil Activation, Vols. 1-4, AFWL-TR-67-41.

3. F. B. K. Kam and F. W. Stallman, Crystal Ball - A Computer Program for Determining Neutron Flux Spectra from Activation Measurements, ORNL/TM-4601 (June 1974).

4. N. M. Greene et al., AMPX: A Modular Code System for Generating Coupled Multigroup Neutron-Garma Libraries from ENDF/B, ORNL/TM-3706 (1974).

5. D. R. Vondy, T. B. Fowler, and G. W. Cunningham, VENTURE: A Code Block for Sulving Multigroup Noutronics Problems Applying the FiniteDifference Diffusion-Theory Approximation to Neutron Transport, ORNL-5062 (October 1975).

6. E. J. Allen and H. T. Kerr, Neutron Flux Computational Model of the Oak Ridge Research Reactor, ORNL/TM-4814 (Apri1 1975).

7. H. T. Kerr, E'. J. Allen, and D. L. Reed, Lattios Displonement, CalcuZations and Comparisons for Different Irradiation Facilities, ORNL/ Tiv-5269 (Hiaicli 1976).

8. T. A. Crockett, personal communication, February 1974.

9. Molten-Salt Reactor Program Semiannu. Progr. Rep. Feb. 28, 1975, ORNL-5047 (September 1975).

10. F. R. Mynatt et al., The Dot III Two-Dimensional Discrete Ordinates Transport Code, ORNL/TM-4280 (September 1973).

11. C. D. Baumann, Neutron Flux Spectra in Experimental Facilities of the Oak Ridge Research Reactor, ORNL-3756 (January 1965). 
ORNL / TM-5 271

UC-77 - Gas-Cooled Reactor Technology

Internal Distribution

$$
\begin{aligned}
& \text { 1-5. E. J. Allen } \\
& \text { 6. C. D. Cagle } \\
& \text { 7. H. P. Carter } \\
& \text { 8. J. F. Clarke } \\
& \text { 9. T. E. Cole } \\
& \text { 10. J. A. Conlin } \\
& \text { 11. J. H. Coobs } \\
& \text { 12. W. E. Cooper } \\
& \text { 13. W. B. Cottrell } \\
& \text { 14. J. A. Cox } \\
& \text { 15. F. L. Culler } \\
& \text { 16. W. P. Eatherly } \\
& \text { 17. J. R. Engel } \\
& \text { 18. K. Farrell } \\
& \text { 19. R. M. Flanders } \\
& \text { 20. G. G. Fee } \\
& \text { 21. M. H. Fontana } \\
& \text { 22. T. B. Fowler } \\
& \text { 23. T. A. Gabriel } \\
& \text { 24. C. B. Gaither } \\
& \text { 25. Uri Gat } \\
& \text { 26. M. J. Goglia } \\
& \text { 27. . N. M. Greene } \\
& \text { 28. T. P. Hamrick } \\
& \text { 29. H. W. Hoffman } \\
& \text { 30. F. J. Homan } \\
& \text { 31. J. Horak } \\
& \text { 32. S. S. Hurt, III } \\
& \text { 33. J. D, Jenkins } \\
& \text { 34. G. H. Jenks } \\
& \text { 35. F. B. K. Kam } \\
& \text { 36. M. J. Kania } \\
& \text { 37-38. P. R. Kasten } \\
& \text { 39-43. H. T. Kerr } \\
& \text { 44. R. W. Knoll } \\
& \text { 45. T. B. Lindemer } \\
& \text { 46. E. L. Long, Jr. } \\
& \text { 47. A. W. Longest }
\end{aligned}
$$

48. A. L. Lotts

49. R. S. Lyon

50. R. E. MacPherson

51. W. J. McCarthy

52. H. E. McCoy

53. S. R. McNeany

54. B. H. Montgomery

55. M. T. Morgan

56. F. R. Mynatt

57. H. A. Parker

58. H. Postma

59. G. L. Ragan

60. E. Ricci

61. M. W. Rosenthal

62. J. E. Rushton

63. J. P. Sanders

64. J. L. Scott

65. R. L. Senn

66. Myrtleen Sheldon

67. T. M. Sims

68. I. Spiewak

69. J. H. Swanks

70. J. J. Taylor

71. W. E. Thomas

72. K. R. Thoms

73. M. L. Tobias

74. T. N. Tiegs

75. D. B. Trauger

76. K: H. Valentine

77. D. R. Vondy

78. T. N. Washburn

79. G. D. Whitman

80. W. J. Wilcox

81. R. M. Young

82. ORNL Patent Office

83-84. Central Research Library

85. Ducument Reference section

86-88. Laboratory Records Department

89. Laboratory Records (RC) 


\section{External Distribution}

90-91. Director, Division of Nuclear Research and Application, ERDA, Washington, D.C. 20545

92. Director, Reactor Division, ERDA, ORO

93. Research and Technical Support Division, ERDA, ORO

94-131. ERDA Exchange Agreements with Germany and Dragon Project

132-298. Technical Information Center, ERDA [For distribution as shown in TID-4500 under category UC-77, Gas-Cooled Reactor Technology (25 copies - NTIS)] 